\title{
Fuel consumption optimization in air transport: a review, classification, critique, simple meta-analysis, and future research implications
}

\author{
Vedant Singh $^{1} \cdot$ Somesh Kumar Sharma ${ }^{1}$
}

Received: 9 March 2014 / Accepted: 16 March 2015 / Published online: 8 April 2015

(C) The Author(s) 2015. This article is published with open access at SpringerLink.com

\begin{abstract}
Objective This paper presents a review, classification schemes, critique, a simple meta-analysis and future research implication of fuel consumption optimization (FCO) literature in the air transport sector. This review is based on 277 articles published in various publication outlets between 1973 and 2014.

Methodology A review of 277 articles related to the FCO in air transport was carried out. It provides an academic database of literature between the periods of 1973- 2014 covering 69 journals and proposes a classification scheme to classify the articles. Twelve hundred of articles were identified and reviewed for their direct relevance to the FCO in air transport. Two hundred seventy seven articles were subsequently selected, reviewed and classified. Each of the 277 selected articles was categorized on four FCO dimensions (Aircraft technology $\&$ design, aviation operations \& infrastructure, socioeconomic $\&$ policy measures, and alternate fuels \& fuel properties). The articles were further classified into six categories of FCO research methodologies (analytical - conceptual, mathematical, statistical, and empirical- experimental, statistical, and case studies) and optimization techniques (linear programming, mixed integer programming, dynamic programming, gradient based algorithms, simulation modeling, and nature based algorithms). In addition, a simple meta-analysis was also carried
\end{abstract}

This article is part of the Topical Collection on Accessibility and Policy Making

Vedant Singh

er.vedu@gmail.com

Somesh Kumar Sharma

somesh.sharma@gmail.com

1 Department of Mechanical Engineering, National Institute of Technology, Hamirpur 177005, HP, India out to enhance understanding of the development and evolution of research in the FCO.

Findings and conclusions This has resulted in the identification of 277 articles from 69 journals by year of publication, journal, and topic area based on the two classification schemes related to FCO research, published between, 1973 to December- 2014. In addition, the study has identified the 4 dimensions and 98 decision variables affecting the fuel consumption. Also, this study has explained the six categories of FCO research methodologies (analytical - conceptual, mathematical, statistical, and empirical-experimental, statistical, and case studies) and optimization techniques (linear programming, mixed integer programming, dynamic programming, gradient based algorithms, simulation modeling, and nature based algorithms). The findings of this study indicate that the analytical-mathematical research methodologies represent the $47 \%$ of FCO research. The results show that there is an increasing trend in research of the FCO. It is observed that the number of published articles between the period 1973 and 2000 is less ( 90 articles), so we can say that there are 187 articles which appeared in various journals and other publication sources in the area of FCO since 2000. Furthermore there is increased trend in research on FCO from 2000 onward. This is due to the fact that continuously new researchers are commencing their research activities in FCO research. This shows clearly that FCO research is a current research area among many research groups across the world. Lastly, the prices of jet fuel have significantly increased since the 2005 . The aviation sector's fuel efficiency improvements have slowed down since the 1970s1980s due to the slower pace of technological development in engine and aerodynamic designs and airframe materials.

We conclude that FCO models need to address the composite fuel consumption problem by extending models to include all the dimensions, i.e. aircraft technology \& design, aviation operations \& infrastructure, socioeconomic \& policy 
measures, and alternative fuels \& fuel properties. FCO models typically comprise all the four dimensions and this reality need to be taken into account in global FCO models. In addition, these models should have objectives or constraints to evaluate the aircraft sizes according to market structure, impact of various policy measures on fuel burn, and near term potential alternative fuel options in the global FCO problem. In the models reviewed, we evaluated that, only the few authors considered these factors. The literature identifies 98 decision variables affecting the fuel consumption related to various dimensions in air transport. So we can conclude that this analysis could represent the informational framework for FCO research in air transport.

Future scope Our analysis provides a roadmap to guide future research and facilitate knowledge accumulation and creation concerning the application of optimization techniques in fuel consumption of air transport. The addressed dimensions \& decision variables could be of potential value to future researchers on the aviation fuel consumption optimization research and is also capable of further refinements. In future, for fuel consumption optimization the explored decision variables could be checked for their reliability and validity and a statistically significant model with minimum number of decision variable could be developed. Further, on the basis of this statistical significant model and with the best market requirement for transport aircraft, the researchers can frame the objective function for fuel consumption minimization problem \& decide their dependent variables, independent variables, constant, and constraints. Furthermore, this study will also provide the base for fuel conservation, energy efficiency, and emission reduction in the aviation sector.

Keywords Air transport industry · Meta-analysis · Aircraft fuel efficiency $\cdot$ Fuel consumption optimization (FCO)

\section{Introduction}

Air Transport industry acts as a catalyst to the economic and social development of a nation. This industry encompasses all those activities which involve transportation of goods and people, by air. Air transport connects people, countries and cultures across the face of the globe. Additionally, it opens up a market to global players, thereby supporting trade and tourism significantly.

The Air transport industry has contributed significantly to the growth of commerce, communication, trade and tourism globally. In spite of a marked expansion, the air transport industry is faced with major issues like high fuel consumption, fuel prices, air traffic growth, competition, economic crisis, aviation emission, safety, design and operational challenges. In this study, fuel consumption has been considered, to be a major challenge for the air transport industry. Attributable to high oil prices and an escalation of competition, fuel consumption is rapidly becoming a critical aspect of the air transport industry. Widespread improvement in the global economy during the past year has also contributed to the demand of oil, thereby inflating its price. David L. Greene [1] pointed out that in the early 1970s, air transport doubled its energy efficiency and restrained the growth rate of fuel. In spite of this improvement, energy use by commercial air carriers grew at an annual rate of $2 \%$ from 1970 to 1987. Mohammad Mazraati [2] concluded upon continuously increasing fuel consumption and air traffic. According to this study, world aviation oil demand was $1.18 \mathrm{MB} / \mathrm{d}$ in 1971 , and reached $4.9 \mathrm{MB} / \mathrm{d}$ in 2006 . The aviation sector accounts for about $5.8 \%$ of total oil consumption worldwide. Aviation fuel consumption today corresponds to between 2 and $3 \%$ of total fossil fuel use worldwide, more than $80 \%$ of which is used by civil aviation [3]. Emma Nygren et al. [4] predicted that traffic will grow $5 \%$ per year to 2026 and fuel demand $3 \%$ per year. According to Schlumberger [5] the demand for jet fuel and aviation gasoline in the air transport sector is projected to reach $14 \%$ of fuel demand in transportation in 2035, compared to $12 \%$ in 2009 .

Fuel consumption is one of major direct operating cost parameter in the air transport industry [6,7]. Air transport fuel remains the most significant and variable component of operating costs and managing this aspect is an increasing challenge for the air transport sector. Airbus [8] predicted that in 2003, fuel represented about $28 \%$ of total operating cost for a typical A320 family operator. But in the near future, it could be more than $45 \%$ of all operating costs of an aircraft. The economy of a country largely depends on fuel prices. Increases in fuel consumption have an influence on the airlines in two ways; direct impact on the operating cost, and declines the demand for air travel and air cargo. According to Majka A. et al. [9] at one time fuel extraction cost and availability had little impact on the evolution of the air transport industry. Furthermore, aircraft fuel burn is proportional to $\mathrm{CO}_{2}$ emission $[10,11]$. Therefore, as the fuel consumption increases the aviation emission shall also increase and that is a big environmental concern today. Chang et al. [12] pointed that the higher fuel consumption of aircrafts is one of the major cause of inefficiency of airlines. Therefore, in such a highly competitive environment, in order to reduce the direct operating cost of an aircraft the FCO is essential. In this study, the FCO in air transport means finding a minimum value of fuel consumption function of several variables subject to a set of constraints and improving the energy efficiency of the aircraft system. The researchers, airlines, aircraft manufacturer and regulatory organizations are continuously trying to reduce the air transport fuel consumption along with the economic cost of flying an aircraft. Further, this reduction will also lead to the reduction of the greenhouse gas emission, caused by the air transport. But before implementing a customized model of the FCO in air transport it is essential to systematically organize, classify, 
and reviews the published literature and also to identify the factors causing the variation in fuel consumption.

The goal of this study was to examine the historical trends published in fuel consumption optimization (FCO) research studies in air transport industry, and to explore the potential fuel consumption reduction areas in future. We cover the literature that relates to transportation, aerospace sciences, energy \& fuel, and environmental sciences. It is hoped that the finding of this research study can highlight the importance of the FCO in the air transport and provide an insight into current FCO research for both academics and air transport industry. The content of this paper is organized as follows: first, the research methodology used in the study is described; second, the methods for classifying FCO research is presented; third, a simple meta-analysis of FCO research are proposed, and the results of the classification are reported; and finally, the conclusions, future research implications, and limitations of the study are discussed.

\section{Research methodology}

As the nature of research in the FCO in air transport is difficult to confine to specific disciplines, the relevant materials are scattered across various journals. A number of journals have very few articles on FCO to their name, making it difficult to gain credible simplistic inferences regarding the focus of research in a particular direction. Hence the research journals reviewed have been grouped discipline wise, i.e. Transportation (TP), Aerospace Sciences (AS), Fuel \& Energy (F\&E), and Environmental Science (ES); all of them being relevant to FCO research.

This gave us some broad fields of foray into the study of the FCO in aviation, letting us draw inferences on the trends in research and research output density in these particular fields. The studies that were selected for inclusion in this study were identified from online electronic databases since from 1973 to 2014. A computerized search of the literature was conducted utilizing Science Direct, Springer Link, Emerald Insight, Jstor, Taylor \& Francis, AIAA Journal, SAE Journals, and Google Scholar. Keywords for the computerized search of the literature were: "air transportation fuel consumption optimization", "fuel efficiency in aviation", "airline fuel conservation", "aviation fuel alternatives", "energy efficiency in aviation", "aviation emission mitigation" and aviation or jet fuel consumption, which identified approximately 1200 articles. After that the full text of each article was reviewed, to eliminate those that were not actually related to FCO research in air transport. The selection process was mainly based on three criteria as follow: (1) only those articles which clearly described how the mentioned FCO techniques and strategies could be applied were selected. (2) Only those articles that had been published in transportation, aerospace sciences, energy \& fuel, and environmental sciences related journals were selected, as these were the most appropriate outlet for FCO research in air transport. (3) Only the papers selected and published in the international journals were included in the study as these journals represents the highest level of research. Unpublished, working papers, conference papers, master and doctoral dissertations and text books were excluded from the study. Based on these criteria we trimmed it down to 277 articles.

Thereafter, each article was carefully reviewed and separately classified according to the four categories of FCO dimensions and seven categories of research methodologies of the FCO in air transport. Though our research may not be exhaustive, it is sufficiently representative for an understanding of FCO research. In addition, this study may suggest/bring light to some unexplored research problems in the area of air transport fuel consumption. The purpose of this paper is mainly descriptive and analytical, thereby not introducing much statistical methodology. Instead, we have conducted a simple meta-analysis to identify trends and patterns in research, in order to shed greater understanding of the development and evolution of research in fuel consumption in the air transport industry and to identify the potential research areas for further research and improvement. We present this simple meta-analysis result in the form of tables and graphs.

\section{Classification method of FCO research in air transport}

\subsection{Classification scheme based on dimensions of FCO in air transport}

Based on the literature review carried out and the nature of FCO research observed in air transport, we have introduced a classification scheme to systematically organize the published articles. From the literature survey of articles we have identified five dimensions (1) Aircraft technology \& design (2) Aviation operations \& infrastructure (3) Socioeconomic \& policy measures (4) Aviation alternate fuels, affecting the fuel consumption in air transport. Figure 1 shows the Classification scheme based on the dimensions of FCO research in air transport. They were further classified from the four major dimensions into their respective decision variables. Hileman et al. [13] suggested the advance aircraft design, operational improvements, and alternative fuels for aviation emission reductions. The result of the study showed that the narrower body aircraft has the greatest potential for fuel burn reduction, but it would require the promotion of innovative aircraft design and extensive use of alternative fuels. Grote et al. [14] addressed the technological, operation$\mathrm{al}$, and policy measures for fuel burn reduction in civil aviation 
Fig. 1 Classification scheme based on dimensions of FCO

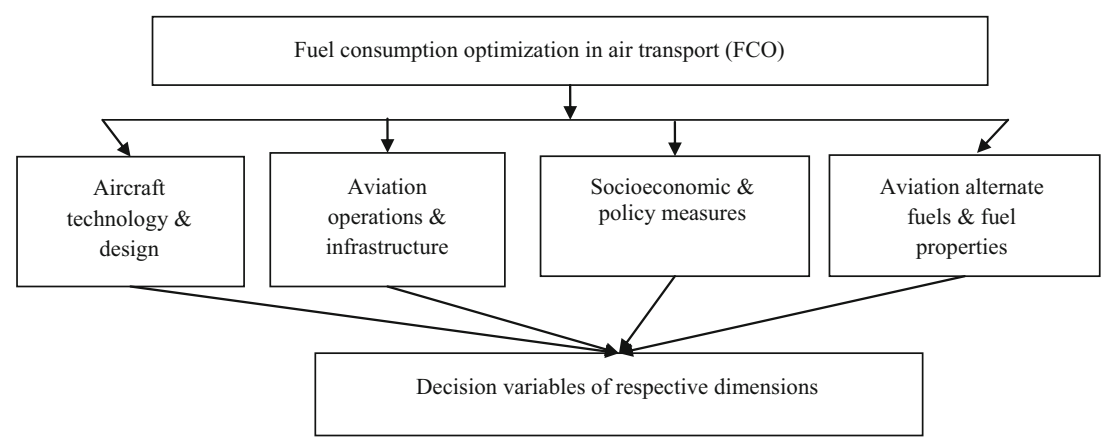

and the analysis of the study showed that some of the measures were directly implemented on the market because they directly reduce the fuel consumption and fuel cost, but some were not due to market constraints.

Sgouridis et al. [15] examined and evaluated the impact of the five policies for reducing emission of commercial aviation; technological efficiency improvement, operational efficiency improvement, use of alternative fuels, demand shift, and carbon pricing. Similarly the study of Lee \& Mo [16]; Green [11]; Lee [3]; Janic [17] and Singh \& Sharma [18] collectively identified the above mentioned dimensions of the FCO.

\subsubsection{Aircraft technology \& design}

Today airlines operate in an increasingly competitive environment caused by the globalization of air transport network worldwide and therefore a necessary condition for airlines are commercially successful is the reduction of direct operating costs, which mainly depends on the technological \& design characteristics of the aircraft used. Technology development is going on at a rapid rate and we can effectively make use of this technological revolution to reduce the fuel consumption of a commercial aircraft. Moreover the fuel consumption of air transport can be reduced through the variety of options such as increased aircraft efficiency, improved operations, use of alternate fuels, socioeconomic measures, and improved infrastructure, but most of the gain so far have been resulted from the aircraft technological improvement. Aircraft technological improvement mainly depends upon the three factors: structural weight, aircraft aerodynamics, and engine specific fuel efficiency [14]. Moreover the aircraft technological efficiency is described by three aircraft performance metrics: engine efficiencies are expressed in terms of thrust specific fuel consumption (TSFC), aerodynamic efficiencies are measured in terms of maximum lift over drag ratio $\left(\mathrm{L}_{\max } / \mathrm{D}\right)$ and structural efficiency is quantified using operating empty weight (OEW) divided by maximum takeoff weight (MTOW) $[19,20]$. Further, Graham et al. [21] have considered the classical range equation in order to understand how the aircraft technology affects the fuel burn. Fuel consumption per payload range of idealized cruise, keeping the aircraft operating parameters fixed are expressed in terms of aerodynamic efficiency, structural efficiency, engine efficiency, and calorific value of the fuel.

In addition the studies of Henderson et al. [10] and Wang et al. [22] explained the fuel burn reduction by considering aircraft technology \& design dimensions. Henderson et al. [10] studied the aircraft design for optimal environmental performance and the design variables considered in this study for optimization problems were from aircraft geometry, engine parameters, and cruise setting. This concludes that the aircraft optimized for minimum fuel burn encompass a high aspect ratio wing with lower induced drag, high bypass ratio engines and high core pressures and temperatures. In addition the mission range and cruise Mach number were also optimized for maximum payload fuel efficiency. Furthermore the possibility of designing larger aircraft for shorter ranges was also examined and result shown that the reduction in structural weight can be achieved by reducing fuel burn. Also, Wang et al. [22] studied the multi objective optimization of aircraft design for emission and cost reduction. A multi-objective optimization of aircraft design for the tradeoff between emission effect and direct operating cost was performed with five geometry variables (i.e. Wing area, aspect ratio, ratio of thickness to chord at root, sweep, and taper ratio), one is mass of the designed fuel for specific range $5000 \mathrm{Km}$, two flight condition parameters (i.e. cruise Mach number and initial cruise altitude) and three performance requirement as constraints (i.e. take off field length, landing field length, and the 2 nd climb gradient). The result of the study showed that, a decrease of $29.8 \%$ in direct operating cost was attained at the expense of an increase of $10.8 \%$ in greenhouse gases. Currently the evolutionary developments of engine technology, airframe technology, and use of advance light weight alloys and composite material, have resulted in a positive trend of fuel efficiency improvements. The merging technology and optimized design dimensions finally lead to the fuel consumption optimization. Aircraft technology \& design have the highest potential to optimize the aviation fuel consumption, and some of their successful applications in the FCO have been proposed in the literature $[1,3,10,11,13-107]$. 


\subsubsection{Aviation operations \& infrastructure}

The amount of fuel consumed by an aircraft during its operation from start-up through to taxi and takeoff, to cruise, to approach for landing and taxiing on arrival, depends upon several factors. Many of the factors can be influenced by airlines with proper operations planning and strategies. The current operational practices are not always optimal from the fuel consumption point of view and hence there is need for operational improvements. Operational improvement can be expressed in term of operational efficiency, which is the combination of ground and airborne efficiency. In general the actual aircraft performance can be determined by how the aircraft is operated subject to operational constraints and the efficient operational procedures are those, in which the actual fuel burn used falls close to the theoretical minimum [14]. Furthermore the operational efficiency can be expressed in term of operational and payload-fuel energy intensity, and the payload factor [13]. Also the operational factors to reduce the fuel consumption per passenger-km include the increasing load factor, optimizing the aircraft speed and fuel weight, limiting the use of auxiliary power, eliminating the non essential weight, and reducing taxiing. In addition, highly sophisticated flight-planning system also improves the aircraft fuel efficiency because this allows pilots to exploit prevailing wind conditions, calculate precise fuel loads \& set different flight levels and speeds for the aircraft to achieve the most economic performance. For a typical flight there are a number of factors such as cruise altitude and speed, mass, and weather conditions that affects the fuel consumption [108]. Therefore, by optimizing the aircraft operations from start-up through to taxi and takeoff, to cruise, to approach for landing and taxiing on arrival, have the significant to reduce the fuel burn.

Aviation infrastructure also plays an important role in fuel consumption optimization. Infrastructure improvements present a major opportunity for fuel consumption reduction in aviation. The design of an airport, including the location of the runways and taxiways relative to terminal buildings, clearly has an effect on aircraft fuel burn, because reduction of delays and decreased taxiing time can provide significant aircraft fuel burn reduction. Airport congestion and improper air traffic management increase the fuel consumption. Airport congestion occurs whenever the actual traffic demand is greater than what the system can handle without the delay. According to Simaiakis et al. [109] airport surface congestion at major airports in the United States and Europe is responsible for increased taxi-out times, fuel burn and emissions. Air Traffic Management (ATM) plays an important role in reducing the environmental impacts of air transportation by reducing the inefficiencies during the operations of an aircraft [110]. Ryerson et al. [111] analyzed the possible fuel savings from Air Traffic Management (ATM) improvements and the study explored the impact of the airborne delay, departure delay, and excess planned flight time, and terminal efficiency in fuel consumption using econometric techniques. In addition the better terminal design can also reduce the fuel consumption. There are a number of ways that airports, airlines and ATM providers can improve the air transportation system to minimize fuel burn and emissions. These include improving the use of the airspace, air traffic control and operations and further improving the use of airspace and air traffic control includes the flexible use of airspace, route redesign, using the new tools and programmes to find most effective route, and reduced separation between the aircraft. Salah [112] developed the model of optimal flight paths taking into consideration jet noise, fuel consumption, constraints and extreme operational limits of the aircraft on approach. The results of this study showed that, the environmental impacts and fuel consumption are reduced by the use of aircraft trajectory optimization during arrivals. Beside this there are some constraints to the improved ATM which includes the air traffic controller (ATC). ATC prevents the ideal trajectory of the aircraft to be flown due to a number of reasons such as safe separation, congested airspace, restricted airspace, delay management and weather avoidance etc. The priorities of controller are also taken into the account. For air traffic controller the safety comes first thereafter the performance. Therefore, by optimizing the aviation infrastructure, there is the potential to reduce fuel consumption. A comprehensive list of the reviewed studies of aviation operations \& infrastructure affecting FCO is presented in the literature $[1,3,7,11-20,32,33,38,40-42$, $44,48,53,54,61,67,69,70,72-75,85,86,94,95,98$, 104-182].

\subsubsection{Socioeconomic \& policy measures}

Aviation is the fastest growing sector of the economy. It provides the number of socioeconomic benefits. There are many socioeconomic \& political factors which affect the airline fuel consumption optimization. If these factors are carefully managed then a significant amount of fuel can be saved. Also the social awareness levels of the society, regarding the impact of the aviation emission on climate change plays a key role in fuel consumption reduction. According to Lee \& Mo [16] currently, the scientific knowledge and the social demand for low-emission aircraft is not strong enough because the general public is not well aware of the harmful impacts of aviation emissions on the global climate. The strong social pressure sends the signal to the government and the government takes the necessary action after scientifically confirming the problem. As in the cases of the automobile emission and aircraft noise significant technological and operational improvements have been reported, because the general public was well aware of the health damages caused by these [3]. Also, the education and awareness are very important social measure in air 
transport and there will be many airline customers who have never thought of aviation emission as an environmental problem. Information should be widely available regarding the impact of flying, so that airlines have the background information they need to understand the changing circumstances of aviation. Informed choice is a key component of the transport demand and environmental policy implication. Furthermore, the economic/policy measures for reducing the fuel consumption includes the emission trading, taxes on aviation fuel, and carbon emission charges [17]. Beside this there are some constraints on the airline operations, training, maintenance \& reservations, planning \& routes, scheduling, airways, and labour, these constraints should be removed for fuel burn reduction [183]. In addition, the economic and policy measures should be introduced in an incremental fashion to give the air transport and consumers time to adjust to the changes. So therefore, by optimizing the socioeconomic $\&$ political factors, we can improve the air transportations fuel efficiency. Studies related to socioeconomic \& policy measures have been proposed in the literature $[2,3,14-20,29,33,41,42,44,53,54,73,74$, 94, 113, 114, 150, 154, 158-160, 172, 183-224].

\subsubsection{Aviation alternative fuels \& fuel properties}

Aviation alternative fuels can also play an important for the optimization of aviation fuel consumption. Since the energy crises of the 1970s, all the aircraft companies, aviation sectors, engine companies, and other government organization are working for practicality of using alternative fuel in aircraft. A viable alternative aviation fuel can stabilize fuel price fluctuation and reduce the reliance from the crude oil. According to Hileman \& Statton [225] economic sustainability, environmental concerns, energy supply diversity, and competition for energy resources are the main drivers for alternative jet fuels development. The replacement for current alternative fuels need no aircraft modifications and can be used with the current aviation system, encompassing existing distribution and refueling infrastructure [226]. Hileman \& Statton examined the criteria for the potential alternative jet fuels and highlighted that the synthetic liquid alternative fuels were compatible with current aircraft fleet, but the economic cost of production and the current lack of feedstock availability limits their near term availability to air transport. In addition the study explored the potential of the alternative aviation fuels: conventional jet fuel from petroleum resources, synthetic jet fuels, biodiesel and bio-kerosene, ethanol and butanol, liquefied natural gas and hydrogen and highlighted the technical feasibility parameters: high energy density, high specific energy, high flash point, low freezing point and vapor pressure, high thermal stability, adequate lubricity, and sufficient aromatic compound content. Janic [17]; Pereira et al. [227], Verstraete [228], and Y1lmaz et al. [229] studied the liquid hydrogen as an alternative fuel for air transport and these studied identifies the important parameters affecting the fuel consumption. Chuck \& Donnelly [230] tested the compatibility of the potential aviation bio-fuels with the Jet A-1 and viscosities, cloud point temperature, flash points, energy content, effect of fuel burn in the range vs. the payload were studied. The result of the study shown that, only the hydrocarbons, matched the range vs. payload of Jet-A1 and the limonene was found to fulfill the required specification. Therefore a suitable alternative fuel can be selected on the basis of a variety of criteria, societal priorities, economic viability, and sustainability considerations, which will further reduce the aviation fuel consumption. Aviation alternative fuels \& fuel properties studies related to FCO have been proposed in the literature $[3,11,13-18,32$, $33,40-42,53,54,59,79,86,94,104,140,150,194$, 225-282].

\subsubsection{Identifications of decision variables based on FCO dimensions}

Further, the decision variables of respective dimensions of FCO were selected from the literature on the basis of the description and examination of the relationships between fuel consumption and respective dimensions \& their variables, logical reasoning, conceptual basis, and strong influence on fuel burn. Theses dimensions $\&$ their respective decision variables affect the fuel consumption in an air transport indirect way and indirectly. As clearly evident from the literature these dimensions are closely related to each other so care has been taken that, a single decision variable cannot be repeated more than one time under the two different dimensions. Table 1 shows the decision variables based on the identified dimensions and the reviewed literature. Table 2 shows the number of decision variables of respective dimension and their percentage. From Table 2 it is clear that the A had the highest percentage of decision variables (48.99\%), while B dimension has $23.47 \%$, and $\mathrm{C}$ has $13.26 \%$ and D has $14.28 \%$ each.

\subsection{Classification scheme based on research methodologies of FCO research}

Figure 2 shows the classification scheme 2 based on the research methodology related to fuel consumption \& optimization studies in air transport. The fuel consumption \& optimization research in air transport on the basis of research methodology could be grouped broadly into two major classifications of analytical and empirical research. Further, they are classified into three subcategories of each major classification, i.e. analytical-conceptual, mathematical, statistical, and empirical-experimental, statistical, and case studies. Furthermore analytical- mathematical techniques include the linear programming, mixed integer programming, dynamic programming, gradient based algorithms, simulation modeling, and nature based algorithms. Analytical research uses the deductive 
Table 1 Identified the decision variables based on the FCO dimensions

Identified dimension Identified decision variables References of FCO

\begin{tabular}{|c|c|c|}
\hline $\begin{array}{l}\text { (A) Aircraft } \\
\text { technology \& } \\
\text { design }\end{array}$ & $\begin{array}{l}\text { 1)Aircraft structural weight } \\
\text { 2)Wing reference area } \\
\text { 3)Wing leading edge sweep } \\
\text { 4)Wing quarter chord sweep } \\
\text { 5)Wing aspect ratio } \\
\text { 6)Wing mid span } \\
\text { 7)Wing dihedral } \\
\text { 8)Wing root thickness to } \\
\text { chord ratio } \\
\text { 9)Wing tip height } \\
\text { 10)Wing span } \\
\text { 11)Wing fuel weight } \\
\text { 12)Wing exposed root chord } \\
\text { 13)Wing quarter chord } \\
\text { sweep } \\
\text { 14)Wing average thickness to } \\
\text { chord ratio } \\
\text { 15)Ultimate load factor } \\
\text { 16)Maximum design speed } \\
\text { 17)Fuselage seat abreast } \\
\text { 18)Fuselage cargo height } \\
\text { 19)Maximum height of } \\
\text { fuselage } \\
\text { 20)Effective maximum } \\
\text { diameter of fuselage } \\
\text { 21)Maximum cabin width of } \\
\text { fuselage } \\
\text { 22)Fuselage nose length } \\
\text { 23)Fuselage parallel length } \\
\text { 24)fuselage tail length } \\
\text { 25)Fuselage cabin length } \\
\text { 26)Fuselage fineness ratio } \\
\text { 27)Horizontal tail area } \\
\text { 28)Horizontal tail span } \\
\text { 29)Horizontal tail aspect ratio } \\
\text { of aircraft from leading } \\
\text { 48)Aerodynamic centre of } \\
\text { aircraft from leading edge } \\
\text { of wing } \\
\text { 31)Verizontal tail taper ratio } \\
\text { 32)Vertical tail area } \\
\text { 33)Vertical tail aspect ratio } \\
\text { 34)Vertical tail taper ratio } \\
\text { 35)Drag type factor } \\
\text { 36)Critical mach number } \\
\text { 37)Aircraft wetted area to } \\
\text { wing reference area ratio } \\
\text { 38)Cruise lift to drag ratio } \\
\text { 39)Oswald efficiency factor } \\
\text { 40)Effective wing aspect } \\
\text { 42)Engine bypass ratio } \\
\text { 43)Number of engines } \\
\text { 44)Engine dry weight } \\
\text { 45)Operating specific fuel } \\
\text { 4) }\end{array}$ & $\begin{array}{c}{[1,3,10,11} \\
13-107]\end{array}$ \\
\hline
\end{tabular}

Table 1 (continued)

\begin{tabular}{|c|c|c|}
\hline Identified dimension & $\begin{array}{l}\text { Identified decision variables } \\
\text { of FCO }\end{array}$ & References \\
\hline $\begin{array}{l}\text { (B) Aviation } \\
\text { operations \& } \\
\text { infrastructure }\end{array}$ & $\begin{array}{l}\text { 49)Maximum takeoff weight } \\
\text { 50)Stage length } \\
\text { 51)Fuel weight } \\
\text { 52)Reserve fuel weight } \\
\text { 53)Payload } \\
\text { 54)Cruise speed } \\
\text { 55)Maximum number of } \\
\text { passenger } \\
\text { 56)Mission passenger } \\
\text { 57)Maximum cabin altitude } \\
\text { differential } \\
\text { 58)Maximum payload weight } \\
\text { 59)Mission payload weight } \\
\text { 60)Takeoff field length } \\
\text { 61)Maximum ceiling } \\
\text { 62)Initial cruise altitude } \\
\text { 63)Landing field length } \\
\text { 64)Weather condition } \\
\text { 65)Flight profile } \\
\text { 66)Pilot Techniques } \\
\text { 67)Aircraft maintenance } \\
\text { 68)Terminal area } \\
\text { 69)Runway } \\
\text { 70)Taxiway } \\
\text { 71)Apron }\end{array}$ & $\begin{array}{l}{[1,3,7,11-20,} \\
\quad 32,33,38, \\
40-42,44,48, \\
53,54,61,67, \\
69,70,72-75, \\
\quad 85,86,94,95, \\
98,104-182]\end{array}$ \\
\hline $\begin{array}{l}\text { (C) Socioeconomic } \\
\& \text { policy } \\
\text { measures }\end{array}$ & $\begin{array}{l}\text { 72)Aircraft scheduling } \\
\text { 73)Fuel prices } \\
\text { 74)Ticket prices } \\
\text { 75)Economic incentives } \\
\text { 76)Labour \& Work Rule } \\
\text { 77)Voluntary Measures } \\
\text { 78)Community Awareness } \\
\text { 79)Social and political } \\
\text { pressure } \\
\text { 80)R \& D funding for } \\
\text { technology } \\
\text { 81)Government regulations } \\
\text { 82)Charges and taxes } \\
\text { 83)Emission trading scheme } \\
\text { 84)Political obstacles }\end{array}$ & $\begin{array}{l}{[2,3,14-20,} \\
29,33,41, \\
42,44,53, \\
54,73,74, \\
\quad 94,113,114, \\
150,154, \\
158-160,172, \\
183-224]\end{array}$ \\
\hline $\begin{array}{l}\text { (D) Alternative fuels } \\
\& \text { fuel properties }\end{array}$ & $\begin{array}{l}\text { 85)Types of alternate fuels } \\
\text { 86)Fuel availability } \\
\text { 87)Energy per unit volume } \\
\text { 88)Energy per unit mass } \\
\text { 89)Aromatics content } \\
\text { 90)Sulphur content } \\
\text { 91)Additives } \\
\text { 92)Boiling point } \\
\text { 93)Flash point } \\
\text { 94)Density } \\
\text { 95)Viscosity } \\
\text { 96)Lubricity } \\
\text { 97)Freezing point } \\
\text { 98)Smoke point }\end{array}$ & $\begin{array}{c}{[3,11,13-18,32,} \\
33,40-42,53, \\
54,59,79,86, \\
94,104,140, \\
150,194, \\
225-282]\end{array}$ \\
\hline
\end{tabular}

methods while the empirical research uses the induction method to arrive at conclusions. Analytical-research consists the logical, mathematical, and statistical methods [283]. Table 3 shows the research methodologies FCO in air transport. 
Table 2 Percentage of identified decision variables of FCO dimensions

\begin{tabular}{llll}
\hline Key & Dimension & No. of Decision Variables & Percentage (\%) \\
\hline A & Aircraft technology \& design & 48 & 48.99 \\
B & Aviation operations \& infrastructure & 23 & 23.47 \\
C & Socioeconomic \& policy measures & 13 & 13.26 \\
D & Alternative fuels \& fuel properties & 14 & 14.28 \\
\hline
\end{tabular}

\subsubsection{Analytical research methodology}

In this study, the analytical research includes the case studies for conceptualization, intro-respective research, and conceptual modeling for fuel consumption research in air transport $[1,3,4,11,13,14,16,19,21,32,34,38,40,41,43-45,49$, 50, 52-54, 57, 59, 61, 73, 79-83, 87, 92, 94, 96, 97, 100, 101, $103,105,106,110,128,140,146,148,151,155,163,164$, 168, 174, 175, 183, 187, 193, 201, 209, 211, 213, 215, 218-220, 225, 231, 232, 236, 258, 267, 273]. Analytical mathematical research develops the new mathematical relationships between closely defined concepts and uses the simulated data to draw the conclusions [284, 285]. Here the analytical-mathematical research for fuel consumption in aviation includes the; fuel burn and emission prediction and forecast for future scenario studies which primarily consist of logical and descriptive modeling $[2,22,25,29,35,37,42,46-48$, $55,63-65,67,69,70,72,75-78,84,85,88-91,93,95,98$, $99,102,104,107,113-115,117,132,133,136,138,147$, 149, 152, 153, 165, 178-182, 184, 188, 190, 191, 199, 212, 244]. Additionally the analytical-mathematical techniques can further be classified into the linear programming [24, 28, 39, $62,108,116,122-125,129,134,150,157,160,162,166$, $170,177,185,192,197,198,203,216,217,221,224]$, mixed integer programming $[12,135,197,221,224]$, dynamic programming $[17,75,76,107,119,154,159,161,171,186$, 189], gradient based methods [26, 27, 30, 31, 36, 51, 56, 60, $71]$, simulation modeling [15, 112, 121, 142, 227, 228], and nature based algorithms $[10,58,66,68,118,120,176]$. These techniques mainly deal with the FCO models that are the main thematic area of this study. Each of these techniques has its own strengths and weaknesses and can be helpful in solving certain types of FCO problems. Mathematical programming models have been demonstrated to be useful analytical tools in optimizing decision-making problems such as those encountered in air transport fuel consumption.

Linear programming (LP) models consist of a linear fuel consumption function which is to be minimized subject to a certain number of constraints [157, 162]. Mixed integer programming (MIP) is applicable when some or all of the variables are restricted to be integers [286]. Dynamic programming is used when sub problems are not independent and we solve the problem by dividing them into sub problem [284]. As the aircraft fuel consumption during its operation is not always linear in nature, therefore complex mathematical relationships are used for the FCO. The mathematical techniques, i.e. linear programming and MIP may not be very effective in solving real world FCO problems, because of the large

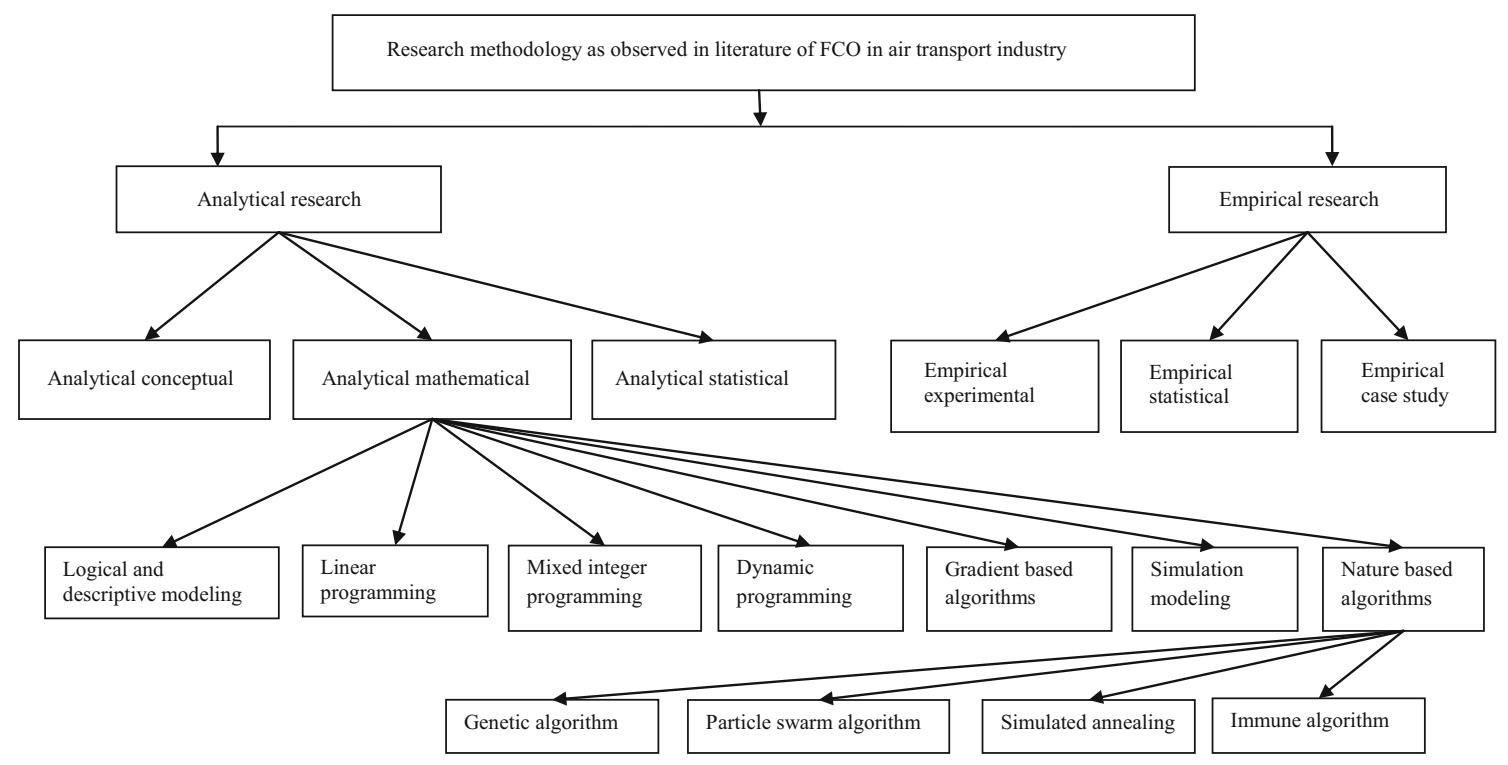

Fig. 2 Classification scheme based on research methodology on fuel consumption \& optimization studies 
Table 3 Research methodologies for FCO research in air transport

\begin{tabular}{|c|c|}
\hline Reference & Research methodology \\
\hline $\begin{array}{l}{[1,3,4,11,13,14,16,19,21,32,34,38,40,41,43-45,49,50,} \\
\quad 52-54,57,59,61,73,79-83,87,92,94,96,97,100,101,103, \\
105,106,110,128,140,146,148,151,155,163,164,168,174, \\
175,183,187,193,201,209,211,213,215,218-220,225,231, \\
232,236,258,267,273]\end{array}$ & Analytical conceptual research \\
\hline $\begin{array}{l}{[2,22,25,29,35,37,42,46-48,55,63-65,67,69,70,72,75-78,} \\
\quad 84,85,88-91,93,95,98,99,102,104,107,113-115,117,132, \\
133,136,138,147,149,152,153,165,178-182,184,188,190, \\
191,199,212,244]\end{array}$ & $\begin{array}{l}\text { Analytical mathematical research- } \\
\text { Logical and descriptive modeling }\end{array}$ \\
\hline $\begin{array}{l}{[24,28,39,45,62,108,116,122-125,129,134,157,160,162} \\
\quad 166,170,177,185,192,197,198,203,216,217,221]\end{array}$ & $\begin{array}{l}\text { Analytical mathematical - Linear } \\
\text { programming }\end{array}$ \\
\hline$[12,135,197,221,224]$ & $\begin{array}{l}\text { Analytical mathematical -Mixed } \\
\text { integer programming }\end{array}$ \\
\hline$[17,75,76,107,119,154,159,161,171,186,189]$ & $\begin{array}{l}\text { Analytical mathematical -Dynamic } \\
\text { programming }\end{array}$ \\
\hline$[26,27,30,31,36,51,56,60,71]$ & $\begin{array}{l}\text { Analytical mathematical- Gradient } \\
\text { based algorithms }\end{array}$ \\
\hline \multirow[t]{5}{*}[10,58,66,68,118,120,176]{} & $\begin{array}{l}\text { Analytical mathematical- Nature } \\
\text { based algorithm: }\end{array}$ \\
\hline & Genetic algorithms \\
\hline & Particle swarm algorithms \\
\hline & Simulated annealing \\
\hline & Immune algorithm \\
\hline$[15,112,121,142,227,228]$ & $\begin{array}{l}\text { Analytical mathematical- Simulation } \\
\text { modelling }\end{array}$ \\
\hline$[20,23,109,111,130,137,144,145,156,158]$ & Analytical statistical research \\
\hline$[18,126]$ & Empirical statistical research \\
\hline $\begin{array}{l}{[86,204,229,230,233-235,238-240,243,245-247,250-252,} \\
\quad 256,259,261,263-265,268-271,281,282]\end{array}$ & Empirical experimental research \\
\hline $\begin{array}{l}{[131,138,141,167,169,172,187,194,195,205-208,210,214,} \\
222,223,226,237,241,242,248,253-255,257,260,262, \\
266,272,274-280]\end{array}$ & Empirical case study \\
\hline
\end{tabular}

number of variables and constraints involved. These are only suitable for solving the FCO problems with limited variables and constraints and also LP require high computer memory and long CPU time in order to process complex mathematical algorithms [287]. Linear programming has shown to be incapable of describing the actual complexity of realism of FCO models. Also the dynamic programming has the limitations: lack of general algorithms and dimensionality [284].

Gradient based methods are mainly used for aerodynamic design optimization of aircraft and they minimize the convex differential functions. Gradient-based methods provide a clear convergence criterion. The limitations of gradient-based methods are; high development cost, noisy objective function spaces, inaccurate gradients, categorical variables, and topology optimization [285]. This limits their use for global FCO. Simulation modeling in the area of the FCO is used to observe how an aircraft performs, diagnose problems and predict the effect of changes in the aircraft system, evaluates fuel consumption, and suggest possible solutions for improvements. Simulation techniques can be ideal for reproducing the behaviors of a complex design system of the aircraft. Many previous studies have analyzed the capability of simulation modeling in fuel consumption modeling and optimization $[15,112,121,142,227,228]$. One of the major limitations of simulation techniques is its inability to guarantee optimality of the developed solution. Also the simulation technique is very expansive.

The nature based algorithms can be based on swarm intelligence, biological systems, physical and chemical systems [288]. The researchers have learned from biological systems, physical and chemical systems to design and develop a number of different kinds of optimization algorithms that have been widely used in both theoretical study and practical applications. Since the nature is the main source of inspiration of these algorithms, so they are called nature based algorithms [288, 289]. In FCO problems the nature based algorithms are classified into the genetic algorithm (GA), particle swarm optimization (PSO), simulated annealing, and immune algorithm. GA is an evolutionary based stochastic optimization algorithm with general-purpose search methods which 
simulate the processes in a natural evolution system [290]. GA is an efficient algorithm with flexibility to search the complex spaces such as the solution space for the global air transport fuel consumption. GA algorithms are well suited to multiobjective optimization problems because they can handle large populations of solutions [58]. The advantages of using GA techniques for solving large optimization problems are its ability to solve multidimensional, non-differential, non-continuous, and even nonparametric problems [291]. Moreover, it solves the problem with multi solutions. GAs has been proven to be a highly effective and efficient tool in solving complex aircraft design, and some of their successful applications in the optimization of fuel consumption models have been proposed in the literature $[58,68,176]$. There are, however, a number of challenges when designing a customized GA procedure to solve a certain FCO problem. The first difficulty is the construction of customized genetic operators to perform the mating process on the chromosomes. Secondly, designing a constraint handling mechanism is generally a complicated task in order to ensure the effective implementation of the model constraints. In addition, when populations have a lot of subjects, there is no absolute assurance that a genetic algorithm will find a global optimum [290]. PSO has been extensively used to many engineering optimization areas due to its simple conceptual framework, unique searching mechanism, computational efficiency, and easy implementation [290]. In order to find the optimal solution, the PSO algorithm simulates the movement of a set of particles in the search space under predetermined rules [292]. The particles use the experience accumulated during the evolution, for finding the global maximum or minimum of a function [118]. The PSO algorithm does not require sorting of fitness values of solutions in any process and this might be a significant computational advantage over GA, especially when the population size is large [293].

Simulated annealing (SA) is a one of the most common meta-heuristics techniques, and has been successfully applied to solve several types of combinational optimization problems [294]. The main advantages of SA are; it deals with arbitrary systems and cost functions, relatively easy to code, even for complex problems. But its main disadvantage is that, it cannot tell whether it has found an optimal solution, it requires some complimentary bound [295]. Pant, R. [66] used SA for the aircraft configuration and flight profile optimization. In case of aircraft fuel consumption, the objective function was found to be highly nonlinear and discontinuous, with several combinations of design variables not having a feasible solution. Hence, gradient-based optimization methods could not be applied to obtain the optimal solution, and the SA approach was adopted [66]. Ravizza, S. et al., [120] adopted the population based immune algorithm for tradeoff between the taxi time and fuel consumption in airport ground movement. Immune Algorithms are related to the Artificial Immune Systems field of study concerned with computational methods. Immune Algorithms are inspired by the process and mechanisms of the biological immune system. The main advantages of the algorithm are dynamically adjustable population size, combination of local with global search, defined convergence criterion, and the capability of maintaining stable local optimum solutions [296]. More knowledge about the fuel-based objective function is needed to formulate the combined FCO function. Lastly the analytical-statistical research integrates logical, mathematical models from analytical-research and statistical models from empirical research for fuel consumption \& optimization research. Table 2 shows the list of analytical statistical studies [20, 23, 109, 111, 130, 137, 144, 145, 156, 158]. Summarily, the main objective of analytical statistical research is to provide, the more cohesive model for empirical statistical testing [283].

\subsubsection{Empirical research methodology}

The empirical research methodology uses data from external organizations or businesses to test if relationships hold in the external world [283]. Empirical research methods for fuel consumption \& optimization studies are classified into three sub-categories, namely; empirical-experimental [86, 204, 229, 230, 233-235, 238-240, 243, 245-247, 250-252, 256, 259, 261, 263-265, 268-271, 281, 282], empirical statistical [18, 126], and empirical case studies [131, 138, 141, 167, 169, 172, 187, 194, 195, 205-208, 210, 214, 222, 223, 226, 237, 241, 242, 248, 253-255, 257, 260, 262, 266, 272, 274-280]. The empirical-experimental research examines the relationships by manipulating controlled treatments to determine the exact effect on specific dependent variables [283, 297]. The empirical- experimental research methodology for fuel consumption \& optimization studies are mainly consist of fuel properties and optimization studies. The main advantage of using the empirical-experimental research is, it may understand and respond more appropriately to dynamics of situations of fuel consumption. The main purpose of empirical statistical research methodologies is to empirically verify theoretical relationships in larger populations from actual practices for reducing the number of relationships for future application [283, 297]. Literature reports the two empirical statistical analyses [18, 126], in which fuel consumption models are tested for their reliability and validity. Lastly, the empirical case study examines the organizations across time and provides the dynamic dimension to theory for promoting the theoretical concepts [283]. Moreover, the empirical case studies provide new conceptual insights by empirically investigating individual cases of complex fuel consumption relations of the real world. 


\section{A simple meta-analysis}

In general, the nature of data available in the studies reviewed determines the type of meta-analytic method that can be applied. In this paper, we perform summary counts of the determinants of the article studied, fuel prices, and evolution of fuel efficiency trends. Though this simple metaanalysis provides only descriptive information with no statistics, it is expected to shed greater understanding of the development and evolution of FCO research trends in the air transport industry and to identify potential research areas for further research and for improvement. Accordingly, we analyzed 277 articles related to FCO research in air transport by (1) Yearly distribution of articles, and evolution of fuel prices and fuel efficiency trends (2) Distribution of research methodologies (3) Journal wise (Discipline) distribution.

\subsection{Yearly distribution of research articles, fuel prices and evolution of fuel efficiency trends}

Progresses in literature related to fuel consumption have been started since after 1973-74 Arab oil embargoes. After that, the oil crises fuel conservation and efficiency became the main focus of the aviation industry. Table 4 Yearly distributions of research articles, fuel prices, and evolution of fuel efficiency trends of air transport from 1973 to 2014 [298]. The major growth in optimum use of fuel occurred after the 1973 Arab oil embargo. During the period 1973-1980, the oil prices increased sharply and U.S. economy had focused the need for more fuel efficient transportation [98]. The first oil shock was in 1973-1974 and the second one in 1978-1980 [16]. During the period 1973-1975, the oil prices increased sharply as shown in Table 4, while the airline jet fuel prices stabilized in 1976 compared to sharply rising prices in the three preceding years. The jet fuel price in 1975 rose to about 2.01 dollar/ million BTU, from the 1.54 dollar/ million BTU in 1974 . During the period 1973-1975, the net average percentage change in fuel prices was $51 \%$ and during the period 19761978 , the fuel prices increased by an amount $8-13 \%$, this shows the stability of jet fuel prices. But, again during the period (1978-1980) second oil shock the jet fuel prices increased sharply, by net average percentage $49 \%$ and this was only $2 \%$ less than the 1973-1975 time periods. Also increased air travel volume was one more main reason behind the rising fuel prices, because the passengers were relatively unconcerned to the ticket price because the benefits of faster travel and this was a very interesting trend in that period [16]. Table 4 shows the distribution of research articles during the period 1973-1980. Total number of articles from 1973 to 1980 were 38 and most of the studies have been found in 1978 i.e.9. It is clear from the Table 4, that the numbers of the articles during the first oil shock (1973-1975) were 9 and after first oil shock and second oil shock, they have been increased to 29. Figure 3 shows the yearly distribution of a number of articles and fuel prices.

In the early 1980s, the non OPEC countries had also started production of oil therefore oil consuming counties decreased their oil demand from OPEC countries. As a result the OPEC production declined after 1981 and in response to declining production. Furthermore, Iran and Iraq war, and ceasing of oil production by Saudi Arabia were the main reasons for fuel price decline [299]. During the period 1981-1985 the US airline jet fuel prices declined from 7.49 to 6.51 dollar/ million BTU and also the net average $\%$ decline in fuel prices was $3.4 \%$. But, the biggest decline in jet fuel prices occurred in 1986, during this year the jet fuel prices decreased by $32 \%$ as compared to 1985 prices. After, the 1986 to 1989 the fuel prices stabilized with net average \% change of only $2 \%$. Again, in 1989 the fuel prices increased by $28 \%$ as compared to 1988 prices. The 1990 spike was mainly attributable to the first Gulf War, but the price spike was only for shorter periods [299]. It is clear from the Fig. 3 that the fuel prices from 1973 to 1981 increased continuously and from 1981 to 1989 decreased continuously. The total numbers of articles during this period were 23. Most of the studies have been found in 1987 i.e. 8. During the period 1981-1990, the number of articles also decreased as compared to 1973-1980.

In the period 1991-2003 the jet fuel prices remained relatively low and stable. During the period 1991-1995, the fuel prices continuously decreased and they fell from 5.18 to 4.04 dollar/million BTU. In 1998 oil prices were affected by the Asian financial crisis. They fell to below $25 \%$ as that of 1997 jet fuel prices. But, the Asian economies recovering from the financial crisis, prices increased during 2000 . The fuel prices rose by $63 \%$ as compared to that of 1999 prices. The total number of articles from 1991 to 2003 were 61 and most of the studies have been found in 2003 i.e.9. The numbers of the articles were more than the last two decades.

During 2004-2014 world aviation fuel consumption and its production increased to a greater extent. The rising demands of countries such as China and India, and political instability in Venezuela, Nigeria, Russia and particularly Middle East have troubled oil supplies and raising prices [300]. From Fig. 3 it is clear that the fuel prices rose sharply from 2002 to 2008 and during the period 2004-2009, the fuel prices experienced large fluctuations from 2004 to 2009. In 2008 jet fuel prices reached levels more than three times those of 2003. While in 2009 fuel prices fell from their 2008 high, and it all most reached half of 2008 fuel prices. This spike and decline in jet fuel prices have demonstrated uncertainty in the magnitude of future fuel prices. Again, in 2011 the jet fuel prices rose by 6.34 dollar/million BTU more than those of 2010 and after that from 2012 to 2014 they decline net average $\%$ of 6.20. During the period 2004-2014 the numbers of research studies have also been increased. Table 4 shows, the 
Table 4 Yearly distributions of research articles, fuel prices, and evolution of fuel efficiency trends [298]

\begin{tabular}{|c|c|c|c|c|}
\hline Year & $\begin{array}{l}\text { No. of } \\
\text { Articles }\end{array}$ & Evolution of fuel efficiency trends research trends & References & $\begin{array}{l}\text { Jet fuel prices (dollar/ } \\
\text { million BTU) }\end{array}$ \\
\hline 1973 & 3 & Turbojet revolution, fuel burning rate study & {$[102,103,281]$} & 0.89 \\
\hline 1974 & 5 & $\begin{array}{l}\text { Operational efficiency, socioeconomic and political } \\
\text { measures, aircraft size }\end{array}$ & {$[174,175,183,222,223]$} & 1.54 \\
\hline 1975 & 1 & Hydrogen fuel & {$[280]$} & 2.01 \\
\hline 1976 & 7 & $\begin{array}{l}\text { Turbofan } 1 \text { st generation, policy measures, Hydrogen fuel, } \\
\text { operational efficiency }\end{array}$ & $\begin{array}{l}{[101,171-173,220,221,} \\
279]\end{array}$ & 2.18 \\
\hline 1977 & 7 & Aircraft size, turboprop potential, fuel management model & {$[96-100,170,278]$} & 2.51 \\
\hline 1978 & 9 & $\begin{array}{l}\text { Fuel combustion requirement, future turbofan, hydrogen } \\
\text { fuel, airport and terminal design, }\end{array}$ & $\begin{array}{l}{[92-95,168,169} \\
\text { 275-277]; }\end{array}$ & 2.86 \\
\hline 1979 & 2 & Engine efficiency, airport capacity & {$[91,167]$} & 3.85 \\
\hline 1980 & 4 & $\begin{array}{l}\text { Turbofan } 2 \text { nd generation, and 3rd generation aircraft design, } \\
\text { hydrogen fuel }\end{array}$ & {$[88-90,274]$} & 6.27 \\
\hline 1981 & 1 & Fuel allocation model & {$[166]$} & 7.49 \\
\hline 1982 & 3 & Fuel burn estimation & {$[85-87]$} & 7.02 \\
\hline 1983 & 1 & Hydrogen fuel & {$[182]$} & 6.94 \\
\hline 1984 & 2 & Aircraft design, fuel consumption estimation & {$[106,165]$} & 6.87 \\
\hline 1985 & 1 & Turbofan performance estimation & {$[84]$} & 6.51 \\
\hline 1986 & 2 & Advance turboprop, Aircraft material potential & {$[82,83]$} & 4.42 \\
\hline 1987 & 8 & $\begin{array}{l}\text { Alternative fuels, hydrogen fuel, fuel prices, modern } \\
\text { turboprop, optimal cyclic cruise }\end{array}$ & $\begin{array}{l}{[79-81,107,219} \\
\quad 270-272]\end{array}$ & 4.55 \\
\hline 1988 & 1 & Variable wing camber & {$[78]$} & 4.15 \\
\hline 1989 & 3 & Aerodynamic efficiency, fuel properties & {$[77,268,269]$} & 4.70 \\
\hline 1990 & 1 & Ground efficiency & {$[164]$} & 6.03 \\
\hline 1991 & 2 & Hydrogen fuel, terminal area traffic management & {$[163,267]$} & 5.18 \\
\hline 1992 & 5 & $\begin{array}{l}\text { Hydrogen fuel, endurance performance optimization, fuel } \\
\text { management model, optimum cruise lift }\end{array}$ & {$[1,75,76,162,266]$} & 4.84 \\
\hline 1993 & 1 & Thermal stability of jet fuel & {$[282]$} & 4.47 \\
\hline 1994 & 5 & Fuel properties, taxation policy, fuel consumption modeling & {$[161,218,263-265]$} & 4.14 \\
\hline 1995 & 2 & Policy measures & {$[73,74]$} & 4.04 \\
\hline 1996 & 5 & $\begin{array}{l}\text { Wave rotor optimization, hydrogen fuel \& fuel properties, } \\
\text { engine design }\end{array}$ & {$[71,72,105,261,262]$} & 4.88 \\
\hline 1997 & 5 & $\begin{array}{l}\text { Alternatives fuels \& fuel properties, cruise range } \\
\text { performance and prediction }\end{array}$ & {$[70,257-260]$} & 4.53 \\
\hline 1998 & 2 & Terminal airdrome, policy measures & {$[69,160]$} & 3.40 \\
\hline 1999 & 5 & $\begin{array}{l}\text { Turbofan engine design and flight profile optimization, } \\
\text { incentive based regulations }\end{array}$ & {$[65-68,217]$} & 4.23 \\
\hline 2000 & 2 & Aircraft turnaround efficiency, chemical kinetic model & {$[159,256]$} & 6.90 \\
\hline 2001 & 5 & $\begin{array}{l}\text { Technological and operational efficiency, policy options, } \\
\text { turbofan and turbojet engine }\end{array}$ & {$[20,63,158,216,255]$} & 5.79 \\
\hline 2002 & 5 & $\begin{array}{l}\text { Airport infrastructure, technological and operational } \\
\text { efficiency, socioeconomic and policy options }\end{array}$ & {$[7,19,157,214,215]$} & 5.54 \\
\hline 2003 & 9 & $\begin{array}{l}\text { Biodiesel and fuel properties, aircraft size, socioeconomic } \\
\text { and policy options, engine performance optimization }\end{array}$ & $\begin{array}{l}{[61,62,154-156,213} \\
\quad 252-254]\end{array}$ & 6.76 \\
\hline 2004 & 5 & $\begin{array}{l}\text { Blended wing body, technological measures, alternative } \\
\text { fuels, infrastructure, socioeconomic \& policy options }\end{array}$ & {$[59,60,152,153,212]$} & 9.06 \\
\hline 2005 & 6 & $\begin{array}{l}\text { Aircraft design optimization, fuel management model, } \\
\text { alternative fuels, operational and socioeconomic \& } \\
\text { policy measures }\end{array}$ & {$[57,58,150,151,211,251]$} & 13.10 \\
\hline 2006 & 8 & $\begin{array}{l}\text { Technological and operational efficiency, fuel properties } \\
\text { optimization, turbofan engine optimization }\end{array}$ & $\begin{array}{l}{[55,56,113,114,148,149} \\
\quad 249,250]\end{array}$ & 14.89 \\
\hline 2007 & 13 & $\begin{array}{l}\text { Airport infrastructure, alternative fuels \& fuel properties, } \\
\text { SAGE model, operational efficiency, aircraft size }\end{array}$ & $\begin{array}{l}{[52-54,143-147,209} \\
210,246-248]\end{array}$ & 16.46 \\
\hline 2008 & 12 & $\begin{array}{l}\text { Hydrogen fuel and fuel properties, operational and } \\
\text { technological efficiency, aircraft landing scheduling }\end{array}$ & $\begin{array}{l}{[48-51,142,178-181} \\
224,244,245]\end{array}$ & 23.13 \\
\hline 2009 & 13 & $\begin{array}{l}\text { Socioeconomic \& policy measure, alternative fuels \& fuel } \\
\text { properties, technological and operational efficiency }\end{array}$ & $\begin{array}{l}{[11,42-47,137-140,208} \\
243]\end{array}$ & 12.64 \\
\hline
\end{tabular}


Table 4 (continued)

\begin{tabular}{|c|c|c|c|c|}
\hline Year & $\begin{array}{l}\text { No. of } \\
\text { Articles }\end{array}$ & Evolution of fuel efficiency trends research trends & References & $\begin{array}{l}\text { Jet fuel prices (dollar/ } \\
\text { million BTU) }\end{array}$ \\
\hline 2010 & 21 & $\begin{array}{l}\text { Technological \& operational efficiency, Socioeconomic \& } \\
\text { policy measure, alternative fuels \& fuel properties }\end{array}$ & $\begin{array}{l}{[2,3,37-41,104,134-136} \\
\quad 202-207,240-242]\end{array}$ & 16.43 \\
\hline 2011 & 18 & $\begin{array}{l}\text { Technological \& operational efficiency, Socioeconomic \& } \\
\text { policy measure, alternative fuels \& fuel properties }\end{array}$ & $\begin{array}{l}{[15,16,34-36,129-133} \\
\quad 199-201,236-239]\end{array}$ & 22.77 \\
\hline 2012 & 16 & $\begin{array}{l}\text { Technological \& operational efficiency, Socioeconomic \& } \\
\text { policy measure, alternative fuels \& fuel properties }\end{array}$ & $\begin{array}{l}{[10,32,33,123-128} \\
\quad 196-198,229,233-235]\end{array}$ & 24.44 \\
\hline 2013 & 22 & $\begin{array}{l}\text { Geared turbofan, Technological \& operational efficiency, } \\
\text { Socioeconomic \& policy measure, alternative fuels \& } \\
\text { fuel properties }\end{array}$ & $\begin{array}{r}{[13,29-31,118-122,177} \\
187-195,228,231,232]\end{array}$ & 23.30 \\
\hline 2014 & 28 & $\begin{array}{l}\text { Technological \& operational efficiency, Socioeconomic \& } \\
\text { policy measure, alternative fuels \& fuel properties }\end{array}$ & $\begin{array}{l}{[12,14,17,18,21-28} \\
108-112,115-117,176 \\
184-186,225-227,230]\end{array}$ & 22.58 \\
\hline Total & 277 & & & \\
\hline
\end{tabular}

total numbers of articles from 2004 to 2014 were 165, which is more than the number of articles than from 1973 to 2003. Most of the studies have been found in 2014 i.e. 28 . Figure 3 shows the increasing trend of number of articles from 2004 to 2007 and during the same period the oil prices had also increased. But in the last 2 years the total numbers of articles were 50, and this represents the $18 \%$ of the total number of articles. From Table 4 it is observed that the number of published articles between the period 1973 and 2000 is less (90 articles), than that of the period 2001-2014.

Historically, jet fuel prices have been the main driver for improvements in aircraft fuel efficiency [16]. Table 4 also shows the yearly evolution of the fuel efficiency trends from

Table 5 Percentage (\%) of research methodologies for FCO research

\begin{tabular}{ll}
\hline Research methodology of FCO research & $\begin{array}{l}\text { Percentage (\%) of } \\
\text { research methodologies }\end{array}$
\end{tabular}

A. Analytical research :

1) Analytical conceptual research 26

2) Analytical mathematical: 22

a) Logical and descriptive modeling 10

b) Linear programming

c) Mixed integer programming 2

d) Dynamic programming 4

e) Gradient based algorithms 3

f) Nature based algorithm

h) Simulation modeling

3) Analytical statistical research 2

4

B. Empirical research

1) Empirical statistical research

2) Empirical experimental research 10

3) Empirical case study 14

Total:

100
1973 to 2014. Evolution of fuel efficiency trends has explored the four factors .i.e. technological efficiency improvement, operational efficiency improvement, socioeconomic \& policy measures, and alternate fuel use, similar as that identified earlier. But, the alternative fuels have only shown the future potential options for fuel efficiency improvement, because of concerns regarding their economic cost of production and the current lack of feedstock availability limits their near term availability of aviation [225]. So, only the improvement in aircraft fuel efficiency from 1960 to 2014 were mainly due to technological factors, operational factors, load factors, and aircraft size. The various trends evolved in the Table 4 are also grouped under these four factors. From Table 4 it is clear that the entire fuel efficiency factor have been evolved continuously from 2007 to 2014, as compared to other time span. According to Grote, [14] average fuel-efficiency improvement between 1960 and 2008 was $1.5 \%$ per annum, but over the time it has slowed down. Lee et al. [20] predicted that the reduction in energy intensity during the period 1959-1995 were mainly due to improvement in engine efficiency (57\%), aerodynamic efficiency (22\%), aircraft capacity (17\%), and other changes such as increased aircraft size (4\%). Owen, [301] showed a $70 \%$ improvement in fuel efficiency as fuel per RPK between 1970 and 2006 and these improvements were mainly due to improvements in load factor $(20 \%)$, aircraft size $(26 \%)$ and finally technical and operational improvements to the fleet $(24 \%)$. However a great part of this improvement was gained during the 1970-1980 (40\%) and rest of improvements had been achieved during 1980-1990 (22\%), 1990-2000 (23\%), and 2000-2006 (15\%). Figure 4 shows the evolution of fuel efficiency trends in US domestic and international aviation from 1970 to 2013. It is clear from Fig. 4 that the US domestic and international airlines passengers' air traffic, fuel consumption decreased from 9 liters $/ 100 \mathrm{Km}$ to 3 liters $/ 100 \mathrm{Km}$ and 10 liter $/ 100 \mathrm{Km}$ to 4 liters/100Km during the time period from 1970 to 2013. 
Fig. 3 Yearly distribution of number of articles and jet fuel prices

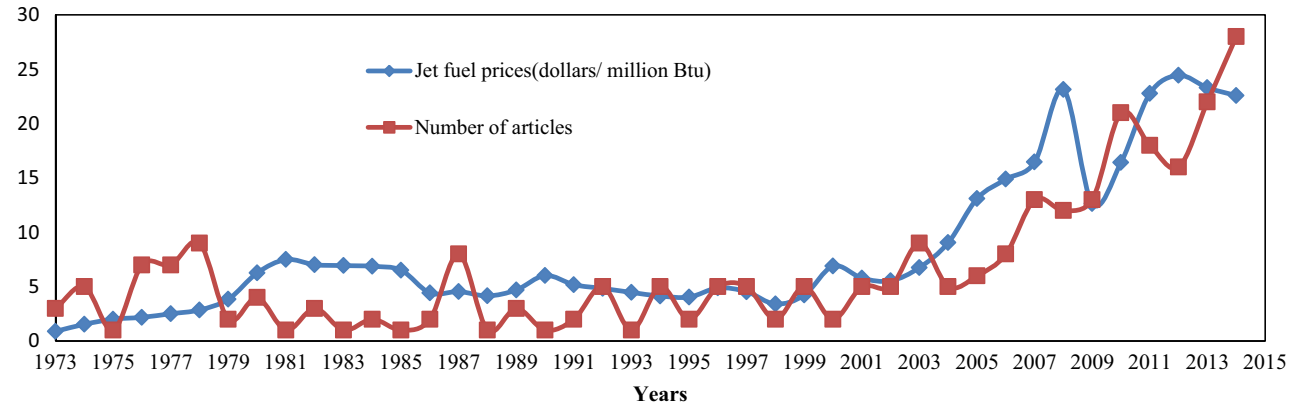

Improvements were particularly rapidly during the 1970s, when wide body aircraft came into the service and in the early to mid-1980s, when mid-range aircraft like turbofan 2 nd and third generation entered into the service. Figure 4 shows the $60 \%$ and $52 \%$ reduction of fuel burn of US domestic and international airlines on a seat-Km (passengers only) during the time period 1970-1985. The flattening slope of the fuel burns curve in Fig. 4 suggests a notable decrease in the rate of fuel efficiency improvement over the time period 1985-2000. Through 1985-2000, we estimate that the efficiency of aircraft improved $15 \%$ for both airlines. Lastly, the figure shows that the fuel efficiency improvement of $9 \%$ and $11 \%$ for the domestic and international US airlines during the time period 2001-2014.

\subsection{Distribution of articles by research methodologies of FCO research}

Table 5 shows the percentage distribution of research methodologies for the FCO research in air transport. It is clear from the Table 5 that the analytical research methodologies have the higher percentage $(75 \%)$ than the empirical research methodologies $(15 \%)$. Also, the near about haft of the research methodologies are from the analytical- conceptual, logical, and descriptive modeling. These studies mainly include the; fuel burn and emission calculation, prediction and forecast for future scenario. Moreover, the analytical-conceptual, logical, and descriptive modeling, empirical-experimental and, empirical case studies are more predominately proposed by many researchers $72 \%$ of methodologies rather than $21 \%$ methodologies of optimization modeling. It is also observed from Table 5 that the optimization modeling research techniques, i.e. Linear programming, dynamic programming, MIP, gradient based methods, and natural algorithms have very low percentage $(21 \%)$.

\subsection{Distribution of articles by journals (discipline wise)}

The journal wise the number of FCO research articles in international journals is computed and the same is shown in Table 6. During the period 1973 to 2014 there are 277 research articles on FCO research appeared in 69 journals and most of the article have been found in Journal of Air Transport Management (9\%) followed by Transportation Research Part D: Transport and Environment, and International journal of Hydrogen Energy both having $7 \%$ each. Since the numbers of articles against many journals are few to get some simple inferences, the research journals reviewed are grouped with respect to disciple wise, i.e. Transportations (TP), Aerospace Sciences (AS), Fuel \& Energy (F\&E) and Environmental Science (ES). Table 6 shows the discipline wise total \% of the articles. Accordingly, distribution of articles of journals (discipline wise) is computed and shown in Fig. 5. It is observed that the Transportation (TP) related journals have far the most articles i.e. 111. This indicates that TP is a major important field affecting the FCO in air transport. Followed to TP related journals, the Aerospace sciences (AS) are having more articles on FCO research. The differences between the
Fig. 4 Evolution of fuel efficiency trends in US domestic and international aviation from 1970 to 2013 [302]

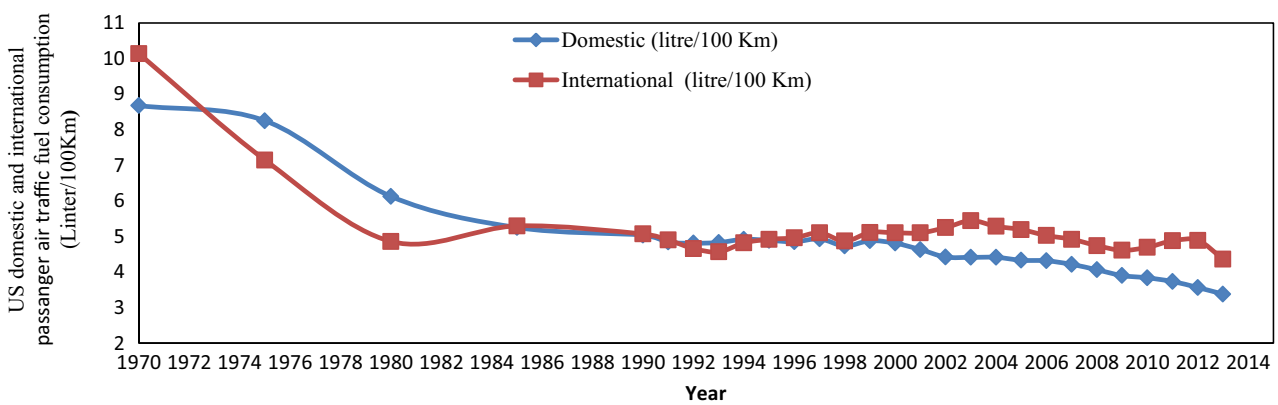


Table 6 The discipline wise total $\%$ of articles

\begin{tabular}{|c|c|c|c|c|}
\hline SI. No. & Journal name & $\begin{array}{l}\text { No. of } \\
\text { articles }\end{array}$ & $\begin{array}{l}\text { Discipline } \\
\text { code }\end{array}$ & $\begin{array}{l}\text { Discipline total } \\
\& \% \text { articles }\end{array}$ \\
\hline 1. & Journal of Air-Transport Management & 26 & $\mathrm{TP}$ & \multirow[t]{26}{*}{$111[40 \%]$} \\
\hline 2. & Transportation Research Part D: Transport and Environment & 19 & $\mathrm{TP}$ & \\
\hline 3. & Transport Policy & 10 & $\mathrm{TP}$ & \\
\hline 4. & Transportation Research Part A: Policy and Practice & 6 & $\mathrm{TP}$ & \\
\hline 5. & Journal of Transport Economics and Policy & 6 & $\mathrm{TP}$ & \\
\hline 6. & Transportation Research & 5 & $\mathrm{TP}$ & \\
\hline 7. & Transportation Journal & 4 & $\mathrm{TP}$ & \\
\hline 8. & Transportation Planning and Technology & 4 & $\mathrm{TP}$ & \\
\hline 9. & Transportation Research Part E: Logistics and Transportation & 3 & $\mathrm{TP}$ & \\
\hline 10. & European Transport Research Review & 3 & $\mathrm{TP}$ & \\
\hline 11. & Journal of Air Transportation & 2 & $\mathrm{TP}$ & \\
\hline 12. & Transportation Research Part B: Methodological & 2 & $\mathrm{TP}$ & \\
\hline 13. & Transportation Research Part C: Emerging Technologies & 2 & $\mathrm{TP}$ & \\
\hline 14. & Transportation Science & 1 & ТP & \\
\hline 15. & Transport Reviews & 1 & ТP & \\
\hline 16 & Journal of Advance Transportation & 1 & ТP & \\
\hline 17. & Public Transport & 1 & TP & \\
\hline 18. & Journal of Transport Geography & 1 & $\mathrm{TP}$ & \\
\hline 19. & Technology Analysis \& Strategic Management & 4 & ТP & \\
\hline 20. & Interfaces & 3 & $\mathrm{TP}$ & \\
\hline 21. & Operations Research & 2 & $\mathrm{TP}$ & \\
\hline 22. & European Journal of Operational Research & 1 & $\mathrm{TP}$ & \\
\hline 23. & Journal of Technology Management \& Innovation & 1 & $\mathrm{TP}$ & \\
\hline 24. & Management Science & 1 & $\mathrm{TP}$ & \\
\hline 25. & The Journal of Operational Research Society & 1 & $\mathrm{TP}$ & \\
\hline 26. & Industrial Engineering Letter & 1 & $\mathrm{TP}$ & \\
\hline 27. & Aircraft Engineering and Aerospace Technology & 14 & AS & \multirow[t]{20}{*}{$89[32 \%]$} \\
\hline 28 & Journal of Aircraft & 14 & AS & \\
\hline 29. & Progress in Aerospace Sciences & 12 & AS & \\
\hline 30. & Aerospace Science and Technology & 10 & AS & \\
\hline 31. & Journal of Propulsion and Power & 8 & AS & \\
\hline 32. & The Aeronautical Journal & 6 & AS & \\
\hline 33. & AIAA Journal & 4 & AS & \\
\hline 34. & Acta Astronautica & 4 & AS & \\
\hline 35. & Proceeding of Institution of Mechanical Engineers, Part G: Journal of Aerospace Engineering & 2 & AS & \\
\hline 36. & SAE : International Journal of Aerospace & 2 & AS & \\
\hline 37. & Aircraft Design & 2 & AS & \\
\hline 38. & Chinese Journal of Aeronautics & 2 & AS & \\
\hline 39. & Journal of Engineering for Gas Turbines and Power & 2 & AS & \\
\hline 40. & Canadian Aeronautics and Space Journal & 1 & AS & \\
\hline 41. & Technology and Culture & 1 & AS & \\
\hline 42. & Material \& Design & 1 & AS & \\
\hline 43. & Advance Material Research & 1 & AS & \\
\hline 44. & Technological Forecasting and Social Change & 1 & AS & \\
\hline 45. & Automatica & 1 & AS & \\
\hline 46. & Fuzzy Sets and Systems & 1 & AS & \\
\hline 47. & International Journal of Hydrogen Energy & 19 & $\mathrm{~F} \& \mathrm{E}$ & $64[23 \%]$ \\
\hline 48. & Fuel & 11 & $\mathrm{~F} \& \mathrm{E}$ & \\
\hline
\end{tabular}


Table 6 (continued)

\begin{tabular}{|c|c|c|c|c|}
\hline SI. No. & Journal name & $\begin{array}{l}\text { No. of } \\
\text { articles }\end{array}$ & $\begin{array}{l}\text { Discipline } \\
\text { code }\end{array}$ & $\begin{array}{l}\text { Discipline total } \\
\& \% \text { articles }\end{array}$ \\
\hline 49. & Energy Conversion and Management & 5 & $\mathrm{~F} \& \mathrm{E}$ & \\
\hline 50. & Energy & 5 & $\mathrm{~F} \& \mathrm{E}$ & \\
\hline 51. & Energy Policy & 4 & $\mathrm{~F} \& \mathrm{E}$ & \\
\hline 52. & Progress in Energy and Combustion Science & 3 & $\mathrm{~F} \& \mathrm{E}$ & \\
\hline 53. & The OPEC Energy Review & 3 & $\mathrm{~F} \& \mathrm{E}$ & \\
\hline 54. & Proceedings of the Combustion Institute & 2 & $\mathrm{~F} \& \mathrm{E}$ & \\
\hline 55. & Journal of Energy (AIAA) & 2 & $\mathrm{~F} \& \mathrm{E}$ & \\
\hline 56. & Fuel Science and Technology International & 2 & $\mathrm{~F} \& \mathrm{E}$ & \\
\hline 57. & Annual Review of Energy and the Environment & 2 & $F \& E$ & \\
\hline 58. & Applied Energy & 2 & $\mathrm{~F} \& \mathrm{E}$ & \\
\hline 59. & Renewable and Sustainable Energy Reviews & 1 & $\mathrm{~F} \& \mathrm{E}$ & \\
\hline 60. & Combustion and Flame & 1 & $\mathrm{~F} \& \mathrm{E}$ & \\
\hline 61. & Fuel Processing Technology & 1 & $\mathrm{~F} \& \mathrm{E}$ & \\
\hline 62. & Journal of Energy Technologies and Policy & 1 & $\mathrm{~F} \& \mathrm{E}$ & \\
\hline $\begin{array}{l}63 . \\
64\end{array}$ & Atmospheric Environment & $\begin{array}{l}6 \\
2\end{array}$ & $\begin{array}{l}\text { ES } \\
\text { ES }\end{array}$ & $13[5 \%]$ \\
\hline 65. & Environment Science and Policy & 1 & ES & \\
\hline 66. & International Journal of Environmental Research and Public Health & 1 & ES & \\
\hline 67. & Philosophical Transactions: Mathematical, Physical and Engineering Sciences & 1 & ES & \\
\hline 68. & Climate Policy & 1 & ES & \\
\hline \multirow[t]{2}{*}{69.} & Carbon Management & 1 & ES & \\
\hline & Total & 277 & & 100 \\
\hline
\end{tabular}

TP and AS articles are only $8 \%$. This could be due to the fact most of the articles reported in TP are also related to road and rail transport and those were not included in the study. The number of articles that appeared in discipline F\&E and ES are relatively low with discipline TP, and AS. This could be due to the low correlation between the objectives of various studies reported on FCO research in air transport and scope of the respective journals.

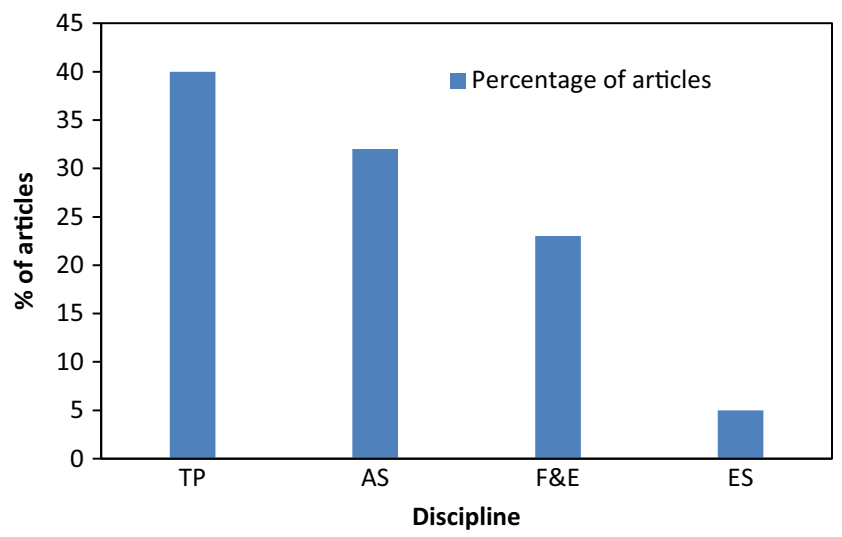

Fig. 5 Discipline wise percentage of articles

\section{Findings, conclusions, direction for future research implications, and limitations}

It is known that the history of the FCO research is not long compared with other industries. To the best of our knowledge, so far, no attempt has been made to classify and analyze the literature dealing with FCO with air transport research. Thus, in this paper we have attempted to review and classify the FCO research. Accordingly, an extensive literature review has been attempted from various journals and web based articles that are possible outlets for this research. This resulted in the identification of 277 articles from 69 journals by year of publication, journal, and topic area based on the two classification schemes related to FCO research, published between, 1973 to December- 2014. In addition, the study has identified the 4 dimensions and 98 decision variables affecting the fuel consumption. Also, this study have explained the six categories of FCO research methodologies (analytical - conceptual, mathematical, statistical, and empirical-experimental, statistical, and case studies) and optimization techniques (linear programming, mixed integer programming, dynamic programming, gradient based algorithms, simulation modeling, and nature based algorithms). The findings of this study indicate that the analytical-mathematical research methodologies 
represent the $47 \%$ of FCO research. The results show that there is an increasing trend in research of the FCO. It is observed that the number of published articles between the period 1973 and 2000 is less (90 articles), so we can say that there are 187 articles which appeared in various journals and other publication sources in the area of FCO since 2000. Furthermore there is increased trend in research on FCO from 2000 onward. This is due to the fact that continuously new researchers are commencing their research activities in FCO research. This shows clearly that FCO research is a current research area among many research groups across the world. Lastly, the prices of jet fuel have significantly increased since the 2005. The aviation sector's fuel efficiency improvements have slowed down since the 1970s-1980s due to the slower pace of technological development in engine and aerodynamic designs and airframe materials.

From the matching of published articles according to our proposed classification schemes and according to performance metric, it seems there are considerable untouched research problems in FCO research. Over the last four decades, the significance of FCO at tactical and operational levels has been recognized by academics and practitioners as a competitive advantage for the better performance of airlines. This study reviewed the state of the art in optimization modeling of fuel consumption. Our findings have some important conclusions of FCO research and suggest the following directions for future research in the area:

- We classified the current literature into four dimensions based on the degree of complexity and identified 98 decision variables affecting the FCO. This classification of dimensions and their respective decision variables could be of potential value to future researchers in the field and is also capable of further refinements. These parameters, if addressed, could result in a consistent, and comparable database of the FCO research.

- We conclude that FCO models need to address the composite fuel consumption problem by extending models to include all the dimensions, i.e. aircraft technology \& design, aviation operations \& infrastructure, socioeconomic $\&$ policy measures, and alternative fuels $\&$ fuel properties. FCO models typically comprise all the four dimensions and this reality need to be taken into account in global FCO models. In addition, these models should have objectives or constraints to evaluate the aircraft sizes according to market structure, impact of various policy measures on fuel burn, and near term potential alternative fuel options in the global FCO problem. In the models reviewed, we evaluated that, only the few authors considered these factors.

- We also conclude that the performance measures (.i.e. technological efficiency and operational efficiency) adopted in FCO models need to be broadened in definition to address socioeconomic \& political and alternative fuels potentials. Although real FCO models emphasize a variety of performance measures in practice - none of FCO models allow for this variety.

- A second classification was also presented in the paper based on the research methodologies and techniques used for tackling the proposed fuel consumption problems. One perpetual concern is the development of appropriate research approaches for tackling large fuel consumption and optimization problems. Various research techniques have been used to deal with aircraft design, operations, infrastructure, socioeconomic \& political, and alternate fuel problems ranging from mathematical models; gradient based algorithms, simulation modeling, and to the latest nature based algorithms. Hence, there is a need to further extend the effectiveness of the existing solution techniques to be capable of handling realistic FCO problems with large numbers of variables and constraints. Heuristics and meta-heuristic techniques are still the dominant solution techniques in the literature of FCO $[10,58$, $66,68,118,120,176]$. Genetic algorithms (GAs), particle swarm optimization (PSO), simulated annealing (SA), and immune algorithm (IA), has been recognized by several researchers as the most promising techniques. There is still a need to further extend the effectiveness of the existing research methodologies and to test the new arrivals such as Ant Colony Optimization (ACO), Bee Colony Optimization (BCO) techniques, and Firefly optimization techniques (FA).

- Only $1 \%$ and $2 \%$ articles discussed the empirical statistical methodology and analytical-mathematical methodology based on the natural algorithms within the context of the FCO. As far as the empirical statistical research methodology is concerned, it verifies models for their empirical validity in larger populations to reduce the number of relationships in future research, while the nature based algorithms has been considered the most powerful tool for optimization. More research could be done on this issue. Therefore, we observed that, the combination of empirical statistical methodology followed by analytical- mathematical nature based algorithms could be of potential research methodologies to future researchers in the field.

- It is observed that the number of published articles between the period 1973 and 2000 is less (90 articles), so we can conclude that there are 187 articles which appeared in various journals and other publication sources in the area of FCO since 2000. With this it is possible to comment that on an average 13 articles per year appeared in journals/other publication sources related to FCO research since 2000. Furthermore there is increased trend in research on FCO from 2000 onward. This is due to the fact that continuously new researchers are commencing their research activities in FCO research. This shows clearly 
that FCO research is a current research area among many research groups across the world.

- The prices of jet fuel have significantly increased since the 2005. If air transport improves their fuel efficiency in response to increase in jet fuel prices, then some of the increases in the cost of air travel can be reduced. The aviation sector's fuel efficiency improvements have slowed down since the 1970s-1980s due to the slower pace of technological development in engine and aerodynamic designs and airframe materials. Technological improvements will take a long time for development, while the operational change is most near-term, could lead to significant reduction in air fares in the face of much higher oil price, but it may not achieve a significant option given the fast increase in air travel demand. Also the study has evolved the various trends of aircraft technological factors, and operational factors for fuel efficiency improvement. These factors could be potential options for the FCO.

- Also an important outcome of the analysis of trends in literature output was that we noticed clear parallels between interest in FCO research and global occurrences related to the oil and energy industry, whether social, political or economic, whether scheduled or sudden; whether positive or degrading to the energy sector. And hence, ultimately, oil prices seem closely related to interest in the FCO.

- In addition a total of 277 articles were classified according to our classifications. We analyzed the identified articles from the 69 journals by year of publication, journal, and topic area. This particular analysis could provide guidelines for the pursuit of future research on FCO and its applications by explaining the chronological growth of aviation fuel efficiency over the years, the challenging areas of fuel efficiency improvement and application, and the major issues surrounding environmental impact, fuel prices, and competitions among the airlines.

- Finally, we acknowledge that this review cannot be claimed to be exhaustive, but it does provide a reasonable insight into the state-of-the-art on FCO research. Thus, it is hoped that this review will provide a source of reference for other researchers/readers interested toward FCO research and help stimulate further interest. Future work will concentrate on the development of an appropriate information framework for FCO research in air transport. After that, this informational framework should be checked for reliability and validity. This leads to the development of a structural model of fuel consumption in the air transport industry and further knowing the relationships among the variables an optimization model will be constructed. Furthermore, this study will also provide the base for fuel conservation, energy efficiency, and emission reduction (As $\mathrm{CO}_{2}$ emission are proportional to aircraft fuel burn) in the aviation sector.
This study might have some limitations. Readers should be cautious in interpreting the result of this study, since the findings are based on the data collected only from the international journal articles. The journals articles were mainly from; Transportations (TP), Fuel \& Energy (F\&E), Aerospace Sciences (AS), and Environmental Sciences (ES). Only, the 69 journal of these disciplines were included in the study. There might be other academic journal which may be able to provide a more comprehensive picture of the articles related to the application of the FCO in air transport. Second, we have reviewed academic/professional journals articles only; conference proceedings and dissertation were excluded, as we assumed that high quality research eventually published in academic/professional journals. Lastly, non-English publications were excluded from this study. We believe research regarding the application of FCO techniques have also been discussed and published in other languages.

Open Access This article is distributed under the terms of the Creative Commons Attribution License which permits any use, distribution, and reproduction in any medium, provided the original author(s) and the source are credited.

\section{References}

1. Greene DL (1992) Energy-efficiency improvement potential of commercial aircraft. Annu Rev Energy Environ 17:537-573

2. Mazraati M (2010) World aviation fuel demand outlook. OPEC Energy Rev 34:42-72

3. Lee JJ (2010) Can we accelerate the improvement of energy efficiency in aircraft systems? Energy Conserv Manag 51:189-196

4. Nygren E, Aleklett K, Höök M (2009) Aviation fuel and future oil production scenarios. Energy Policy 37(10):4003-4010

5. Schlumberger CE, Wang D (2012) Air transport and energy efficiency. The International Bank for Reconstruction and Development / The World Bank, Transport papers TP-38

6. Airbus (2004) Getting to grip with fuel economy. Flight Oper Support Serv 4

7. Stolzer AJ (2002) Fuel consumption modeling of a transport category aircraft using flight operations quality assurance data: a literature review. J Air Transp 7(1):93-102

8. Airbus (2008). Getting to grip with A320 family performance retention and fuel savings. Flight Oper Support Serv 2

9. Majka A, Brusow V, Klepack Z (2007) Fuel Consumption and transportation energy effective analysis. Eur Personal Air Transp Syst Stud, EP- D4.3, SFC-V0, 1-23.

10. Henderson RP, Martins JRRA, Perez RE (2012) Aircraft conceptual design for optimal environmental performance. Aeronaut J 116(1175):1

11. Green JE (2009) The potential for reducing the impact of aviation on climate. Tech Anal Strat Manag 21(1):39-59

12. Chang YT, Park HS, Jeong JB, Lee JW (2014) Evaluating economic and environmental efficiency of global airlines: a SBMDEA approach. Transp Res Part D: Transp Environ 27:46-50

13. Hileman J, De la Rosa Blanco E, Bonnefoy PA, Carter NA (2013) The carbon dioxide challenge facing aviation. Prog Aerosp Sci 63:84-95

14. Grote M, Williams I, Preston J (2014) Direct carbon dioxide emissions from civil aircraft. Atmos Environ 95:214-224 
15. Sgouridis S, Bonnefoy PA, Hansman RJ (2011) Air transportation in a carbon constrained world: long-term dynamics of policies and strategies for mitigating the carbon footprint of commercial aviation. Transp Res A Policy Pract 45(10):1077-1091

16. Lee J, Mo J (2011) Analysis of technological innovation and environmental performance improvement in aviation sector. Int $\mathrm{J}$ Environ Res Public Health 8(9):3777-3795

17. Janić $M(2014)$ Greening commercial air transportation by using liquid hydrogen $\left(\mathrm{LH}_{2}\right)$ as a fuel. Int J Hydrog Energy 39(29):16426-16441

18. Singh V, Sharma SK (2014) Evolving base for the fuel consumption optimization in Indian air transport: application of structural equation modeling. Eur Transp Res Rev 6(3):315-332

19. Babikian R, Lukachko SP, Waitz IA (2002) The historical fuel efficiency characteristics of regional aircraft from technological, operational, and cost perspectives. J Air Transp Manag 8(6):389-400

20. Lee JJ, Lukachko SP, Waitz IA, Schäfer A (2001) Historical and future trends in aircraft performance, cost and emission. Annu Rev Energy Environ 26:167-200

21. Graham W R, Hall C A, Vera Morales M (2014) The potential of future aircraft technology for noise and pollutant emissions reduction. Transp Policy

22. Wang Y, Yin H, Zhang S, Yu X (2014) Multi-objective optimization of aircraft design for emission and cost reductions. Chin $\mathrm{J}$ Aeronaut 27(1):52-58

23. Chang R C (2014) Examination of excessive fuel consumption for transport jet aircraft based on fuzzy-logic models of flight data. Fuzzy Sets Syst

24. Cusher AA, Gopalarathnam A (2014) Drag reduction on aircraft configurations with adaptive lifting surfaces. Aerosp Sci Technol 34:35-44

25. Dray L (2014) Time constant in aviation infrastructure. Transp Policy 34:29-35

26. Della Vecchia P, Nicolosi F (2014) Aerodynamic guidelines in the design and optimization of new regional turboprop aircraft. Aerosp Sci Technol 38:88-104

27. Liem R P, Kenway G K, \& Martins J R (2014) Multi-mission aircraft fuel-burn minimization via multipoint aero-structural optimization. AIAA J 1-19

28. Tsai WH, Chang YC, Lin SJ, Chen HC, Chu PY (2014) A green approach to the weight reduction of aircraft cabins. J Air Transp Manag 40:65-77

29. Dray L (2013) An analysis of the impact of aircraft lifecycles on aviation emissions mitigation policies. J Air Transp Manag 28:62-69

30. Mastroddi F, Gemma S (2013) Analysis of Pareto frontiers for multidisciplinary design optimization of aircraft. Aerosp Sci Technol 28(1):40-55

31. Leifsson L, Ko A, Mason WH, Schetz JA, Grossman B, Haftka RT (2013) Multidisciplinary design optimization of blendedwing-body transport aircraft with distributed propulsion. Aerosp Sci Technol 25(1):16-28

32. Fan W, Sun Y, Zhu T, Wen Y (2012) Emissions of HC, CO, NOx, $\mathrm{CO} 2$, and $\mathrm{SO} 2$ from civil aviation in China in 2010. Atmos Environ 56:52-57

33. Singh V, Sharma SK, Vaibhav S (2012) Identification of dimensions of the optimization of fuel consumption in air transport industry: a literature review. J Energy Technol Policy 2(7):24-33

34. Szodruch J, Grimme W, Blumrich F, Schmid R (2011) Next generation single-aisle aircraft-requirements and technological solutions. J Air Transp Manag 17(1):33-39

35. Drela M (2011) Design Drivers of energy-efficient transport aircraft. SAE Int J Aerosp 4(2):602-618

36. Lee K, Nam T, Perullo C, Mavris DN (2011) Reduced-order modeling of a high-fidelity propulsion system simulation. AIAA J 49(8):1665-1682

37. Ryerson MS, Hansen M (2010) The potential of turboprops for reducing aviation fuel consumption. Transp Res Part D: Transp Environ 15(6):305-314
38. Givoni M, Rietveld P (2010) The environmental implications of airlines' choice of aircraft size. J Air Transp Manag 16(3):159 167

39. Martinez-Val R, Perez E, Puertas J, Roa J (2010) Optimization of planform and cruise conditions of a transport flying wing. Proc Inst Mech Eng G J Aerosp Eng 224(12):1243-1251

40. Agarwal R (2010) Sustainable (green) aviation: challenges and opportunities. SAE Int J Aerosp 2(1):1-20

41. Capoccitti S, Khare A, Mildenberger U (2010) Aviation industrymitigating climate change impacts through technology and policy. J Technol Manag Innov 5(2):66-75

42. Lee DS, Fahey DW, Forster PM, Newton PJ, Wit RC, Lim LL, Sausen R (2009) Aviation and global climate change in the 21st century. Atmos Environ 43(22):3520-3537

43. Morrell P (2009) The potential for European aviation $\mathrm{CO}_{2}$ emissions reduction through the use of larger jet aircraft. J Air Transp Manag 15(4):151-157

44. Lawrence P (2009) Meeting the challenge of aviation emissions: an aircraft industry perspective. Tech Anal Strat Manag 21(1):79 92

45. Parker R (2009) From blue skies to green skies: engine technology to reduce the climate-change impacts of aviation. Tech Anal Strat Manag 21(1):61-78

46. Hall CA, Schwartz E, Hileman JI (2009) Assessment of technologies for the silent aircraft initiative. J Propuls Power 25(6):11531162

47. Mazraati M, Alyousif OM (2009) Aviation fuel demand modelling in OECD and developing countries: impacts of fuel efficiency. OPEC Energy Rev 33:23-46

48. Filippone A (2008) Comprehensive analysis of transport aircraft flight performance. Prog Aerosp Sci 44(3):192-236

49. McDonald CF, Massardo AF, Rodgers C, Stone A (2008) Recuperated gas turbine aeroengines. Part III: engine concepts for reduced emissions, lower fuel consumption, and noise abatement. Aircr Eng Aerosp Technol 80(4):408-426

50. McDonald CF, Massardo AF, Rodgers C, Stone A (2008) Recuperated gas turbine aeroengines, part II: engine design studies following early development testing. Aircr Eng Aerosp Technol 80(3):280-294

51. Werner-Westphal W, Heinze PH (2008) Structural sizing for an unconventional, environment-friendly aircraft configuration within integrated conceptual design. Aerosp Sci Technol 12(2):184 194

52. Kehayas N (2007) Aeronautical technology for future subsonic civil transport aircraft. Aircr Eng Aerosp Technol 79(6):600-610

53. Bows A, Anderson KL (2007) Policy clash: Can projected aviation growth be reconciled with the UK Government's $60 \%$ carbon-reduction target? Transp Policy 14(2):103-110

54. Williams V (2007) The engineering options for mitigating the climate impacts of aviation. Philos Trans R Soc A: Math Phys Eng Sci 365(1861):3047-3059

55. Liew KH, Urip E, Yang SL, Mattingly JD, Marek CJ (2006) Performance cycle analysis of turbofan engine with interstage turbine burner. J Propuls Power 22(2):411-416

56. Najjar YS, Al-Sharif SF (2006) Thermodynamic optimization of the turbofan cycle. Aircr Eng Aerosp Technol 78(6):467-480

57. Akerman J (2005) Sustainable air transport — on track in 2050. Transp Res Part D: Transp Environ 10(2):111-126

58. Antoine NE, Kroo IM (2005) Framework for aircraft conceptual design and environmental performance studies. AIAA J 43(10): 2100-2109

59. Sehra AK, Whitlow W Jr (2004) Propulsion and power for 21st century aviation. Prog Aerosp Sci 40(4):199-235

60. Liebeck RH (2004) Design of blended wing body subsonic transport. J Aircr 41(1): 10-25 
61. Green JE (2003) Civil aviation and the environmental challenge. Aeronaut J 107:281-299

62. Lyantsev OD, Breikin TV, Kulikov GG, Arkov VY (2003) Online performance optimisation of aero engine control system. Automatica 39(12):2115-2121

63. Liu F, Sirignano WA (2001) Turbojet and turbofan engine performance increases through turbine burners. J Propulsion Power 17(3):695-705

64. Bert CW (1999) Range and endurance of turboprop, turbofan, or piston-propeller aircraft having wings with or without camber. Aircr Des 2(4): 183-190

65. Sirignano WA, Liu F (1999) Performance increases for gas-turbine engines through combustion inside the turbine. J Propuls Power 15(1):111-118

66. Pant R, Fielding JP (1999) Aircraft configuration and flight profile optimization using simulated annealing. Aircr Des 2(4):239-255

67. Janić M (1999) Aviation and externalities: the accomplishments and problems. Transp Res Part D: Transp Environ 4(3):159-180

68. Nadon LJJP, Kramer SC, King PI (1999) Multidisciplinary optimization in conceptual design of mixed-stream turbofan engines. J Propuls Power 15(1):17-22

69. Vedantham A, Oppenheimer M (1998) Long-term scenarios for aviation: demand and emissions of $\mathrm{CO}_{2}$ and $\mathrm{NO}_{\mathrm{X}}$. Energy Policy 26(8):625-641

70. Torenbeek E (1997) Cruise performance and range prediction reconsidered. Prog Aerosp Sci 33(5):285-321

71. Wilson J, Paxson DE (1996) Wave rotor optimization for gas turbine engine topping cycles. J Propuls Power 12(4):778-785

72. Lee SH, Le Dilosquer M, Singh R, Rycroft MJ (1996) Further considerations of engine emissions from subsonic aircraft at cruise altitude. Atmos Environ 30(22):3689-3695

73. Komor P (1995) Reducing energy use in US freight transport. Transp Policy 2(2):119-128

74. Charles R A, \& Newman H K (1995) Public policy and technology management: changing the role of government in the operation of air traffic control. Transp J 39-48

75. Sachs G (1992) Optimization of endurance performance. Prog Aerosp Sci 29(2):165-191

76. Rodrigo M-V, Emilio P (1992) Optimum cruise lift coefficient in initial design of jet aircraft. J Aircr 29(4):712-714

77. Klein V (1989) Estimation of aircraft aerodynamic parameters from flight data. Prog Aerosp Sci 26(1):1-77

78. Szodruch J, Hilbig R (1988) Variable wing camber for transport aircraft. Prog Aerosp Sci 25(3):297-328

79. McCarthy P (1987) Future aircraft fuels and their effect on engine control design. Aircr Eng Aerosp Technol 59(12):9-32

80. Saravanamuttoo HIH (1987) Modern turboprop engines. Prog Aerosp Sci 24(3):225-248

81. Velikano DP, Stavrov OA, Zamyatin ML (1987) Energy conservation in transportation. Energy 12(10-11):1047-1055

82. Lange RH (1986) A review of advanced turboprop transport aircraft. Prog Aerosp Sci 23(2):151-166

83. Vogelesang LB, Gunnink JW (1986) ARALL: a material challenge for next generation aircraft. Mater Des 7(6):287-300

84. Oates GC (1985) Performance estimation for turbofans with and without mixers. J Propuls Power 1(3):252-256

85. Collins BP (1982) Estimation of aircraft fuel consumption. J Aircr 19(11):969-975

86. Jackson TA (1982) Fuel property effects on air force gas turbine engines-program genesis. J Energy 6(6):376-383

87. Laughlin TF (1982) One manufacturer's approach to improving jet transport fuel efficiency. Transp Plan Technol 7(3):185-200

88. Satz RW (1980) The solution to the gas turbine temperature problem. Energy Convers Manag 20(1):49-63

89. Tye W (1980) The energy problem - its effect on aircraft design: part 1. Supply and demand. Aircr Eng Aerosp Technol 52(3):9-12
90. Tye W (1980) The energy problem - its effect on aircraft design: part 3 advances in aircraft design. Aircr Eng Aerosp Technol 52(5):2-5

91. Harvey RA, Morris RE, Palfreeman BJ (1979) Aircraft fuel economy the propulsion system contribution. Can Aeronaut Space J 25(1):17-27

92. Wilde G L (1978) Future large civil turbofans and power plants. Aeronaut J 82(811)

93. Denning RM (1978) Energy conserving aircraft from the engine viewpoint. Aircr Eng Aerosp Technol 50(8):27-37

94. Miller MP, Mays RA (1978) Transportation and the U.S. petroleum resource: an aviation perspective. J Energy 2(5):259-268

95. Dow JP, Murphy B, Kohlhoff W (1978) Let's put fuel efficiency into perspective. Aircr Eng Aerosp Technol 50(7):24-27

96. Galloway TL (1977) Advanced short haul aircraft for high density markets. Acta Astronaut 4(1):15-34

97. Foss RL, Hopkins JP (1977) Potential of turboprop powerplants for fuel conservation. Acta Astronaut 4(1):53-75

98. Archibald RB, Reece WS (1977) The impact of the energy crisis on the demand for fuel efficiency: the case of general aviation. Transp Res 11(3):161-165

99. Whitehead AH Jr (1977) The promise of air cargo - system aspects and vehicle design. Acta Astronaut 4(1):77-98

100. Sweet HS (1977) Short haul transport systems and aircraft technology. Acta Astronaut 4(1):35-52

101. Cleveland FA (1976) Challenge to advanced technology transport aircraft systems. J Aircr 13(10):737-744

102. Constant EW (1973) A Model for technological change applied to the turbojet revolution. Technol Cult 14(4):553-572

103. Alexander AJ, Nelson JR (1973) Measuring technological change: aircraft turbine engines. Technol Forecast Soc Chang 5(2):189 203

104. Lee DS et al (2010) Transport impacts on atmosphere and climate: aviation. Atmos Environ 44(37):4678-4734

105. Michaelis L, Davidson O (1996) GHG mitigation in the transport sector. Energy Policy 24(10):969-984

106. Morrison S A (1984) An economic analysis of aircraft design. J Transp Econ Policy 123-143

107. Sachs G, Christodoulou T (1987) Reducing fuel consumption of subsonic aircraft by optimal cyclic cruise. J Aircr 24(9):616-622

108. Turgut ET et al (2014) Fuel flow analysis for cruise phase of commercial aircraft on domestic routes. Aerosp Sci Technol 37: $1-9$

109. Simaiakis I, Balakrishnan H, Khadilkar H, Reynolds TG, Hansman RJ, Reilly B, Urlass S (2014) Demonstration of reduced airport congestion through pushback rate control. Transp Res A Policy Pract 66:251-267

110. Reynolds TG (2014) Air traffic management performance assessment using flight inefficiency metrics. Transp Policy 34:63-74

111. Ryerson MS, Hansen M, Bonn J (2014) Time to burn: flight delay, terminal efficiency, and fuel consumption in the national airspace system. Transp Res A Policy Pract 69:286-298

112. Salah K (2014) Environmental impact reduction of commercial aircraft around airports. Less noise and less fuel consumption. Eur Transp Res Rev 6(1):71-84

113. Nangia RK (2006) Efficiency parameters for modern commercial aircraft. Aeronaut J 110(1110):495-510

114. Nangia R K (2006) Operations and aircraft design towards greener civil aviation using air-to-air refueling. Aeronaut J 705-721

115. Alonsoa G, Benitoa A, Lonzab L, Kousoulidoub M (2014) Investigations on the distribution of air transport traffic and $\mathrm{CO}_{2}$ emissions within the European Union. J Air Transport Manag 36: 85-93

116. O'Kelly ME (2014) Air freight hubs in the FedEx system: analysis of fuel use. J Air Transport Manag 36:1-12 
117. Park Y, O'Kelly ME (2014) Fuel burn rates of commercial passenger aircraft: variations by seat configuration and stage distance. J Transp Geogr 41:137-147

118. Zhang YJ, Xu JX (2013) A novel particles swarm neural network model to optimize aircraft fuel consumption. Adv Mater Res 694: 3370-3374

119. Clarke JP, Brooks J, Nagle G, Scacchioli A, White W, Liu SR (2013) Optimized profile descent arrivals at Los Angeles international airport. J Aircr 50(2):360-369

120. Ravizza S, Chen J, Atkin JA, Burke EK, Stewart P (2013) The trade-off between taxi time and fuel consumption in airport ground movement. Public Transport 5(1-2):25-40

121. Delgado L, Prats X, Sridhar B (2013) Cruise speed reduction for ground delay programs: a case study for San Francisco international airport arrivals. Transport Res C: Emerg Technol 36:83-96

122. Fregnani G, Tavares JA, Müller C, Correia AR (2013) A fuel tankering model applied to a domestic airline network. J Adv Transp 47(4):386-398

123. Delgado L, Prats X (2012) En route speed reduction concept for absorbing air traffic flow management delays. J Aircr 49(1):214 224

124. Khadilkar H, Balakrishnan H (2012) Estimation of aircraft taxi fuel burn using flight data recorder archives. Transp Res Part D: Transp Environ 17(7):532-537

125. Lapp M, Wikenhauser F (2012) Incorporating aircraft efficiency measures into the tail assignment problem. J Air Transport Manag 19:25-30

126. Singh V, Sharma SK, Vaibhav S (2012) Modeling the civil aircraft operations for the optimization of fuel consumption in Indian air transport industry. Ind Eng Lett 2(7):20-29

127. Turgut ET, Rosen MA (2012) Relationship between fuel consumption and altitude for commercial aircraft during descent: preliminary assessment with a genetic algorithm. Aerosp Sci Technol 17(1):65-73

128. Mitchell D, Ekstrand H, Prats X, Grönstedt T (2012) An environmental assessment of air traffic speed constraints in the departure phase of flight: a case study at Gothenburg Landvetter Airport, Sweden. Transp Res Part D: Transp Environ 17(8):610-618

129. Nikoleris T, Gupta G, Kistler M (2011) Detailed estimation of fuel consumption and emissions during aircraft taxi operations at Dallas/Fort Worth International Airport. Transp Res Part D: Transp Environ 16(4):302-308

130. Turgut ET (2011) Estimating aircraft fuel flow for a three-degree flight-path-angle descent. J Aircr 48(3):1099-1106

131. Lucia DJ (2011) Cruising in afterburner: air force fuel use and emerging energy policy. Energy Policy 39(9):5356-5365

132. Howitt OJ, Carruthers MA, Smith IJ, Rodger CJ (2011) Carbon dioxide emissions from international air freight. Atmos Environ 45(39):7036-7045

133. Chèze B, Gastineau P, Chevallier J (2011) Forecasting world and regional aviation jet fuel demands to the mid-term (2025). Energy Policy 39(9):5147-5158

134. Rivas D, Lopez-Garcia O, Esteban S, Gallo E (2010) An analysis of maximum range cruise including wind effects. Aerosp Sci Technol 14(1):38-48

135. Zachary DS, Gervais J, Leopold U (2010) Multi-impact optimization to reduce aviation noise and emissions. Transp Res Part D: Transp Environ 15(2):82-93

136. Filippone A (2010) Cruise altitude flexibility of jet transport aircraft. Aerosp Sci Technol 14(4):283-294

137. Senzig DA, Fleming GG, Iovinelli RJ (2009) Modeling of terminal-area airplane fuel consumption. J Aircr 46(4):1089-1093

138. Miyoshi C, Mason KJ (2009) The carbon emissions of selected airlines and aircraft types in three geographic markets. J Air Transp Manag 15(3):138-147
139. Givoni M, Rietveld P (2009) Airline's choice of aircraft size-explanations and implications. Transp Res A Policy Pract 43(5): 500-510

140. Kemp R (2009) Short-haul aviation-under what conditions is it more environmentally benign than the alternatives? Tech Anal Strat Manag 21(1):115-127

141. Pitfield DE, Caves RE, Quddus MA (2010) Airline strategies for aircraft size and airline frequency with changing demand and competition: a simultaneous-equations approach for traffic on the north Atlantic. Journal of Air Transport Management 16(3):151-158

142. Muller C, Santana ESM (2008) Analysis of flight-operating costs and delays: the Sao Paulo terminal maneuvering area. J Air Transp Manag 14(6):293-296

143. Forsyth $P$ (2007) The impacts of emerging aviation trends on airport infrastructure. J Air Transp Manag 13(1):45-52

144. Lee JJ, Waitz IA, Kim BY, Fleming GG, Maurice L, Holsclaw CA (2007) System for assessing aviation's global emissions (SAGE), part 2: uncertainty assessment. Transp Res Part D: Transp Environ 12(6):381-395

145. Kim BY, Fleming GG, Lee JJ, Waitz IA, Clarke JP, Balasubramanian S, Gupta ML (2007) System for assessing aviation's global emissions (SAGE), Part 1: model description and inventory results. Transp Res Part D: Transp Environ 12(5):325-346

146. Cames M (2007) Tankering strategies for evading emissions trading in aviation. Clim Pol 7(2):104-120

147. Wei W, Hansen M (2007) Airlines' competition in aircraft size and service frequency in duopoly markets. Transp Res E Logist Transp Rev 43(4):409-424

148. McLean D (2006) The operational efficiency of passenger aircraft. Aircr Eng Aerosp Technol 78(1):32-38

149. Swan WM, Adler N (2006) Aircraft trip cost parameters: a function of stage length and seat capacity. Transp Res E Logist Transp Rev 42(2):105-115

150. Abdelghany K, Abdelghany A, Raina S (2005) A model for the airlines' fuel management strategies. J Air Transp Manag 11(4): 199-206

151. Simões AF, Schaeffer R (2005) The Brazilian air transportation sector in the context of global climate change: $\mathrm{CO}_{2}$ emissions and mitigation alternatives. Energy Convers Manag 46(4):501-513

152. Cavcar A, Cavcar M (2004) Approximate solutions of range for constant altitude-constant high subsonic speed flight of transport aircraft. Aerosp Sci Technol 8(6):557-567

153. Cavcar A, Cavcar M (2004) Impact of aircraft performance differences on fuel consumption of aircraft in air traffic management environment. Aircr Eng Aerosp Techn 76(5):502-515

154. Janic M (2003) Modeling operational, economic and environmental performance of an air transport network. Transp Res Part D: Transp Environ 8(6):415-432

155. Upham P, Thomas C, Gillingwater D, Raper D (2003) Environmental capacity and airport operations: current issues and future prospects. J Transp Manag 9(3):145-151

156. Stolzer AJ (2003) Fuel consumption modeling of transport category aircraft: a flight operations quality assurance (FOQA) analysis. J Air Transp 8(2):3-18

157. Zouein PP, Abillama WR, Tohme E (2002) A multiple period capacitated inventory model for airline fuel management: a case study. J Oper Res Soc 53(4):379-386

158. Olsthoorn $X(2001)$ Carbon dioxide emissions from international aviation: 1950-2050. J Air Transp Manag 7(2):87-93

159. Wu CL, Caves RE (2000) Aircraft operational costs and turnaround efficiency at airports. J Air Transp Manag 6(4):201-208

160. Leigh R J, Drake L, \& Thampapillai D J (1998) An economic analysis of terminal aerodrome forecasts with special reference to Sydney Airport. J Transp Econ Policy 377-392

161. Janic M (1994) Modelling extra aircraft fuel consumption in an en route airspace environment. Transp Plan Technol 18(3):163-186 
162. Stroup JS, Wollmer RD (1992) A fuel management model for the airline industry. Oper Res 40(2):229-237

163. Visser HG (1991) Terminal area traffic management. Prog Aerosp Sci 28(4):323-368

164. Fan HS (1990) Fuel conservation by controlling aircraft ground operations. Transp Plan Technol 15(1):1-11

165. Wolf P, Simon W (1984) Energy consumption in air transport: a contribution to the problem of calculating and comparing energy consumption values of jet-propelled civil aircraft. Transp Rev 4(2):159-171

166. Nash B (1981) A simplified alternative to current airline fuel allocation model. Interfaces 11(1):1-9

167. Newell GF (1979) Airport capacity and delays. Transp Science 13(3):201-241

168. Hubbard HB (1978) Terminal airspace/ airport congestion delays. Interfaces 8(2):1-14

169. Walters AA (1978) Airports: an economic survey. J Transp Econ Policy 12(2): 125-160

170. Darnel DW, Loflin C (1977) National airlines fuel management and allocation model. Interfaces 7(2):1-16

171. Speyer JL (1976) Non-optimality of the steady-state cruise for aircraft. AIAA J 14(11):1604-1610

172. Taylor P E, McMILLAN C L A U D E, \& Glover, F (1976) Substituting ground delays for airborne delays - some unresolved policy questions for the air transport industry. Transp J 85-90

173. Barman JF, Erzberger H (1976) Fixed-range optimum trajectories for short-haul aircraft. J Aircr 13(10):748-754

174. Pilati DA (1974) Energy use and conservation alternatives for airplanes. Transp Res 8(4):433-441

175. Hirst E (1974) Direct and indirect energy use for commercial aviation. Transp Res 8(4-5):427-432

176. Patrón, R S F, Berrou Y, \& Botez R M (2014) New methods of optimization of the flight profiles for performance databasemodeled aircraft. Proc Inst Mech Eng Part G: J Aerosp Eng 0954410014561772

177. Dancila BD, Botez R, Labour D (2013) Fuel burn prediction algorithm for cruise, constant speed and level flight segments. Aeronaut J 117(1191):491-504

178. Filippone A (2008) Analysis of carbon-dioxide emissions from transport aircraft. J Aircr 45(1):185-197

179. Mazraati M, Faquih YO (2008) Modelling aviation fuel demand: the case of the United States and China. OPEC Energy Rev 32(4): 323-342

180. Bartel M, Young TM (2008) Simplified thrust and fuel consumption models for modern two-shaft turbofan engines. J Aircr 45(4): $1450-1456$

181. Young TM (2008) Fuel-sensitivity analyses for Jet and pistonpropeller airplanes. J Aircr 45(2):715-719

182. Torenbeek E, Wittenberg H (1983) Generalized maximum specific range performance. J Aircr 20(7):617-622

183. Drake JW (1974) Social, political and economic constraints on airline fuel optimization. Transp Res 8(4):443-449

184. Dray L, Evans A, Reynolds T, Schäfer A W, Vera-Morales M, \& Bosbach W (2014) Airline fleet replacement funded by a carbon tax: an integrated assessment. Transp Policy

185. Rosskopf M, Lehner S, Gollnick V (2014) Economic-environmental trade-offs in long-term airline fleet planning. J Air Transp Manag 34:109-115

186. Khoo H L, \& Teoh L E (2014) A bi-objective dynamic programming approach for airline green fleet planning. Transp Res Part D Transp Environ

187. Adler N, Martini G, Volta N (2013) Measuring the environmental efficiency of the global aviation fleet. Transp Res B Methodol 53: $82-100$
188. Liu W, Lund H, Mathiesen BV (2013) Modelling the transport system in China and evaluating the current strategies towards the sustainable transport development. Energy Policy 58:347-357

189. Naumann M, Suhl L (2013) How does fuel price uncertainty affect strategic airline planning? Oper Res 13(3):343-362

190. Robertson S (2013) High-speed rail's potential for the reduction of carbon dioxide emissions from short haul aviation: a longitudinal study of modal substitution from an energy generation and renewable energy perspective. Transp Plan Technol 36(5):395-412

191. Ryerson M S, \& Kim H (2013) The impact of airline mergers and hub reorganization on aviation fuel consumption. J Clean Prod (In Press)

192. Ryerson MS, Hansen M (2013) Capturing the impact of fuel price on jet aircraft operating costs with Leontief technology and econometric models. Transp Res C Emerg Technol 33:282-296

193. Steven M, Merklein T (2013) The influence of strategic airline alliances in passenger transportation on carbon intensity. J Clean Prod 56:112-120

194. Winchester N, McConnachie D, Wollersheim C, Waitz IA (2013) Economic and emissions impacts of renewable fuel goals for aviation in the US. Transp Res A Policy Pract 58:116-128

195. Winchester N, Wollersheim C, Clewlow R, Jost NC, Paltsev S, Reilly JM, Waitz IA (2013) The impact of climate policy on US aviation. J Transp Econ Policy (JTEP) 47(1):1-15

196. Adler N, Gellman A (2012) Strategies for managing risk in a changing aviation environment. J Transp Manag 21:24-35

197. Tsai WH, Lee KC, Liu JY, Lin HL, Chou YW, Lin SJ (2012) A mixed activity-based costing decision model for green airline fleet planning under the constraints of the European Union Emissions Trading Scheme. Energy 39(1):218-226

198. O'Kelly ME (2012) Fuel burn and environmental implications of airline hub networks. Transp Res Part D: Transp Environ 17(7): $555-567$

199. Hihara K (2011) Analysis on bargaining about global climate change mitigation in international aviation sector.Transportation. Res Part E: Logist Transp Rev 47(3):342-358

200. Vespermann J, Wald A (2011) Much Ado about Nothing?-An analysis of economic impacts and ecologic effects of the EUemission trading scheme in the aviation industry. Transp Res A Policy Pract 45(10):1066-1076

201. Nantke HJ (2011) Emissions trading in aviation. Carbon Manag 2(2):127-134

202. Anger A, Köhler J (2010) Including aviation emissions in the EU ETS: much ado about nothing? A review. Transp Policy 17(1):3846

203. Brueckner JK, Zhang A (2010) Airline emission charges: effects on airfares, service quality, and aircraft design. Transp Res B Methodol 44(8):960-971

204. Yamaguchi K (2010) Voluntary $\mathrm{CO}_{2}$ emissions reduction scheme: analysis of airline voluntary plan in Japan. Transp Res Part D: Transp Environ 15(1):46-50

205. Rothengatter W (2010) Climate change and the contribution of transport: basic facts and the role of aviation. Transp Res Part D: Transp Environ 15(1):5-13

206. Scheelhaase JD (2010) Local emission charges-A new economic instrument at German airports. J Air Transp Manag 16(2):94-99

207. Schaefer M, Scheelhaase J, Grimme W, Maertens S (2010) The economic impact of the upcoming EU emissions trading system on airlines and EU member states - an empirical estimation. Eur Transp Res Rev 2(4):189-200

208. Cook A, Tanner G, Williams V, Meise G (2009) Dynamic cost indexing-managing airline delay costs. J Air transp Manag 15(1): 26-35

209. Solomon DS, Hughey KF (2007) A proposed multi criteria analysis decision support tool for international environmental policy 
issues: a pilot application to emissions control in the international aviation sector. Environ Sci Pol 10(7):645-653

210. Scheelhaase JD, Grimme WG (2007) Emissions trading for international aviation - an estimation of the economic impact on selected European airlines. J Air Transp Manag 13(5):253-263

211. Williams V, Noland RB (2005) Variability of contrail formation conditions and the implications for policies to reduce the climate impacts of aviation. Transp Res Part D: Transp Environ 10(4): 269-280

212. Jamin S, Schäfer A, Ben-Akiva ME, Waitz IA (2004) Aviation emissions and abatement policies in the United States: a city-pair analysis. Transp Res Part D: Transp Environ 9(4):295-317

213. Wei W, Hansen M (2003) Cost economics of aircraft size. J Transp Econ Policy 279-296.

214. Carlsson F, Hammar H (2002) Incentive-based regulation of CO2 emissions from international aviation. J Air Transp Manag 8(6): 365-372

215. Daniel JI (2002) Benefit-cost analysis of airport infrastructure: the case of taxiways. J Air Transp Manag 8(3):149-164

216. Schipper Y, Rietveld P, Nijkamp P (2001) Environmental externalities in air transport markets. J Air Transp Manag 7(3):169-179

217. Carlsson F (1999) Incentive-based environmental regulation of domestic civil aviation in Sweden. Transp Policy 6(2):75-82

218. Alamdari FE, Brewer D (1994) Taxation policy for aircraft emissions. Transp Policy 1(3):149-159

219. Hayashi P M, \& Trapani J M (1987) The impact of energy costs on domestic airline passenger travel. J Transp Econ Policy 73-86

220. Mays RA, Miller MP, Schott JG (1976) Intercity freight fuel utilization at low package densities - airplanes, express trains and trucks. Transp J 16(1):52-75

221. Austin L M, \& Hogan W W (1976) Optimizing the procurement of aviation fuels. Manag Sci 515-527

222. Vittek JF Jr (1974) Short haul aviation: will energy limit its future? Transp Res 8(4):451-455

223. Hirst E (1974) Transportation energy conservation: opportunities and policy issues. Transp J 13(3):42-52

224. Soomer MJ, Franx GJ (2008) Scheduling aircraft landings using airlines' preferences. Eur J Oper Res 190(1):277-291

225. Hileman J I, Stratton R W (2014) Alternative jet fuel feasibility. Transp Policy

226. Withers MR et al (2014) Economic and environmental assessment of liquefied natural gas as a supplemental aircraft fuel. Prog Aerosp Sci 66:17-36

227. Pereira SR, Fontes T, Coelho MC (2014) Can hydrogen or natural gas be alternatives for aviation?-A life cycle assessment. Int J Hydrog Energy 39(25):13266-13275

228. Verstraete D (2013) Long range transport aircraft using hydrogen fuel. Int J Hydrog Energy 38(34):14824-14831

229. Yılmaz İ, İlbaș M, Taștan M, Tarhan C (2012) Investigation of hydrogen usage in aviation industry. Energy Convers Manag 63: 63-69

230. Chuck CJ, Donnelly J (2014) The compatibility of potential bioderived fuels with Jet A-1 aviation kerosene. Appl Energy 118:83-91

231. Khandelwal B, Karakurt A, Sekaran PR, Sethi V, Singh R (2013) Hydrogen powered aircraft: the future of air transport. Prog Aerosp Sci 60:45-59

232. Boretti A, Dorrington G (2013) Are synthetic liquid hydrocarbon fuels the future of more sustainable aviation in Australia? Int $\mathrm{J}$ Hydrog Energy 38(34):14832-14836

233. Wang H, Oehlschlaeger MA (2012) Auto-ignition studies of conventional and Fischer-Tropsch jet fuels. Fuel 98:249-258

234. Kick T, Herbst J, Kathrotia T, Marquetand J, Braun-Unkhoff M, Naumann C, Riedel U (2012) An experimental and modeling study of burning velocities of possible future synthetic jet fuels. Energy 43(1):111-123
235. Hui X, Kumar K, Sung CJ, Edwards T, Gardner D (2012) Experimental studies on the combustion characteristics of alternative jet fuels. Fuel 98:176-182

236. Law CK (2011) Fuel options for next generation chemical propulsion. AIAA J 50(1):19-36

237. Dorbian CS, Wolfe PJ, Waitz IA (2011) Estimating the climate and air quality benefits of aviation fuel and emissions reductions. Atmos Environ 45(16):2750-2759

238. Kumar K, Sung CJ, Hui X (2011) Laminar flame speeds and extinction limits of conventional and alternative jet fuels. Fuel 90(3):1004-1011

239. Blakey S, Rye L, Wilson CW (2011) Aviation gas turbine alternative fuels: a review. Proc Combust Inst 33(2):2863-2885

240. Kumar K, Sung CJ (2010) A comparative experimental study of the autoignition characteristics of alternative and conventional jet fuel/oxidizer mixtures. Fuel 89(10):2853-2863

241. Turgut ET, Rosen MA (2010) Partial substitution of hydrogen for conventional fuel in an aircraft by utilizing unused cargo compartment space. Int J Hydrog Energy 35(3):1463-1473

242. Janic $M(2010)$ Is liquid hydrogen a solution for mitigating air pollution by airports? Int J Hydrog Energy 35(5):2190-2202

243. Nojoumi H, Dincer I, Naterer GF (2009) Greenhouse gas emissions assessment of hydrogen and kerosene-fueled aircraft propulsion. Int J Hydrog Energy 34(3):1363-1369

244. Janic M (2008) The potential of liquid hydrogen for the future 'carbon-neutral' air transport system. Transp Res Part D: Transp Environ 13(7):428-435

245. Balster LM, Corporan E, DeWitt MJ, Edwards JT, Ervin JS, Graham JL, Zabarnick S (2008) Development of an advanced, thermally stable, coal-based jet fuel. Fuel Process Technol 89(4): 364-378

246. Liu G, Wang L, Qu H, Shen H, Zhang X, Zhang S, Mi Z (2007) Artificial neural network approaches on composition-property relationships of jet fuels based on GC-MS. Fuel 86(16):2551-2559

247. Holley AT, Dong Y, Andac MG, Egolfopoulos FN, Edwards T (2007) Ignition and extinction of non-premixed flames of singlecomponent liquid hydrocarbons, jet fuels, and their surrogates. Proc Combust Inst 31(1):1205-1213

248. Edwards T (2007) Advancements in gas turbine fuels from 1943 to 2005. J Eng Gas Turbines Power 129(1):13-20

249. Dagaut P, Cathonnet M (2006) The ignition, oxidation, and combustion of kerosene: a review of experimental and kinetic modeling. Prog Energy Combust Sci 32(1):48-92

250. Ibarreta AF, Sung CJ (2006) Optimization of Jet-A fuel reforming for aerospace applications. Int J Hydrog Energy 31(8):1066-1078

251. Aksit IM, Moss JB (2005) Model fuels to reproduce the sooting behaviour of aviation kerosene. Fuel 84:239-254

252. Arkoudeas P, Kalligeros S, Zannikos F, Anastopoulos G, Karonis D, Korres D, Lois E (2003) Study of using JP-8 aviation fuel and biodiesel in CI engines. Energy Convers Manag 44(7):1013-1025

253. Wardle DA (2003) Global sale of green air travel supported using biodiesel. Renew Sust Energ Rev 7(1):1-64

254. Edwards T (2003) Liquid fuels and propellants for aerospace propulsion: 1903-2003. J Propuls Power 19(6):1089-1107

255. Maurice LQ, Lander H, Edwards T, Harrison WE III (2001) Advanced aviation fuels: a look ahead via a historical perspective. Fuel 80(5):747-756

256. Lindstedt RP, Maurice LQ (2000) Detailed chemical-kinetic model for aviation fuels. J Propuls Power 16(2):187-195

257. Taylor FA (1997) Hydrogen and other alternative fuels for air and ground transportation. J Air Transp Manag 3(2):102-104

258. Contreras A, Yigit S, Ozay K, Veziroglu TN (1997) Hydrogen as aviation fuel: a comparison with hydrocarbon fuels. Int J Hydrog Energy 22(10-11):1053-1060

259. Pohl HW, Malychev VV (1997) Hydrogen in future civil aviation. Int J Hydrog Energy 22(10):1061-1069 
260. Armstrong FW, Allen JE, Denning RM (1997) Fuel related issues concerning the future of aviation. Proc Inst Mech Eng Part G: J Aerosp Eng 211(1):1-11

261. Goodger EM (1996) Jet fuels. Aircr Eng Aerosp Techn 68(5):3-6

262. Berry GD, Pasternak AD, Rambach GD, Ray Smith J, Schock RN (1996) Hydrogen as a future transportation fuel. Energy 21(4): 289-303

263. Nagpal JM, Sharma RL, Sagu ML, Tiwari GB (1994) Combustion performance related properties of aviation turbine fuels. Fuel Sci Technol Int 12(4):613-630

264. Heneghan SP, Zabarnick S (1994) Oxidation of jet fuels and the formation of deposit. Fuel 73(1):35-43

265. Pruitt DS, Hardy DR (1994) Analysis of instability deposit to thermal in aviation jet fuels. Fuel Sci Technol Int 12(7-8):10351049

266. Veziroglu TN, Barbir F (1992) Hydrogen: the wonder fuel. Int J Hydrog Energy 17(6):391-404

267. Price RO (1991) Liquid hydrogen - an alternative aviation fuel? Int J Hydrog Energy 16(8):557-562

268. Cheng CP, Wang SR, Huang YH, Chang SC, Tang CP (1989) Spectrophotometric studies of storage stability of jet fuel. Fuel 68(2):264-267

269. Zuber K, Bartl P (1989) Quality control of aviation fuels: 1. Automatic simulated distillation and calculation of the vapour pressure of JP-4 aviation fuel (AVTAG) using capillary gas chromatography. Fuel 68(5):659-663

270. Alder HP (1987) Hydrogen in air transportation. Feasibility study for Zurich airport, Switzerland. Report of the Swiss Group. Int J Hydrog Energy 12(8):571-585

271. Mukherjee NL (1987) Comparison of hydrogenated shale oils with standard jet fuels. Fuel Process Technol 17(2):117-129

272. Marchetti C (1987) The future of hydrogen - an analysis at world level with a special look at air transports. Int J Hydrog Energy 12(2):61-71

273. Wilkinson KG (1983) An airline view of $\mathrm{LH}_{2}$ as a fuel for commercial aircraft. Int J Hydrog Energy 8(10):793-796

274. Veziroglu TN (1980) Next step in aviation. Int J Hydrogen Energy 5:117-118

275. Mikolowsky WT, Noggle LW (1978) The potential of liquid hydrogen as a military aircraft fuel. Int J Hydrog Energy 3(4):449460

276. Brewer GD (1978) Hydrogen usage in air transportation. Int J Hydrog Energy 3(2):217-229

277. Blazowski WS (1978) Future jet fuel combustion problems and requirements. Prog Energy Combust Sci 4(3):177-199

278. Longwell JP (1977) Synthetic fuels and combustion. Prog Energy Combust Sci 3(2):127-138

279. Brewer GD (1976) Aviation usage of liquid hydrogen fuel — prospects and problems. Int J Hydrog Energy 1(1):65-88

280. Dell RM, Bridger NJ (1975) Hydrogen - the ultimate fuel. Appl Energy 1(4):279-292

281. Knapton JD, Stobie IC, Krier H (1973) Burning rate studies of fuel air mixtures at high pressures. Combust Flame 21(2):211-220

282. Heneghan SP, Martel CR, Williams TF, Ballal DR (1993) Studies of jet fuel thermal stability in a flowing system. J Eng Gas Turbines Power 115(3):480-485
283. Wacker JG (1998) A definition of theory: research guidelines for different theory-building research methods in operations management. J Oper Manag 16(4):361-385

284. Skiena SS (2008) Dynamic Programming. Springer, London, pp 273-315

285. Zingg DW, Nemec M, Pulliam TH (2008) A comparative evaluation of genetic and gradient-based algorithms applied to aerodynamic optimization. Eur J Comput Mech/Revue Européenne de Mécanique Numérique 17(1-2):103-126

286. Bronson R, Naadimuthu G (1982) Schaum's outline of theory and problems of operations research. McGraw-Hill, New York

287. Dantzig G B (1998) Linear programming and extensions. Princeton University Press

288. Fister Jr I, Yang X S, Fister I, Brest J, \& Fister D (2013) A brief review of nature-inspired algorithms for optimization. arXiv preprint arXiv:1307.4186

289. Zang H, Zhang S, Hapeshi K (2010) A review of nature-inspired algorithms. J Bionic Eng 7:S232-S237

290. Binitha S, Sathya SS (2012) A survey of bio inspired optimization algorithms. Int J Soft Comput Eng 2(2):137-151

291. Gen M, \& Cheng R (2000) Genetic algorithms and engineering optimization, vol. 7. John Wiley \& Sons

292. Zhang S, Lee CKM, Chan HK, Choy KL, Wu Z (2015) Swarm intelligence applied in green logistics: A literature review. Eng Appl Artif Intell 37:154-169

293. Kachitvichyanukul V (2012) Comparison of three evolutionary algorithms: GA, PSO, and DE. Ind Eng Manag Syst 11(3):215223

294. Xiao Y, Zhao Q, Kaku I, Xu Y (2012) Development of a fuel consumption optimization model for the capacitated vehicle routing problem. Comput Oper Res 39(7):1419-1431

295. Rutenbar RA (1989) Simulated annealing algorithms: an overview. Circuits Devices Mag IEEE 5(1):19-26

296. De Castro L N, \& Timmis J (2002) An artificial immune network for multimodal function optimization. In Evolutionary Computation, 2002. CEC'02. Proceedings of the 2002 Congress on (Vol. 1, pp. 699-704) IEEE

297. Meredith JR, Raturi A, Amoako-Gyampah K, Kaplan B (1989) Alternative research paradigms in operations. J Oper Manag 8(4): 297-326

298. New York Energy Prices Retail energy price data https://data.ny. gov/Energy-Environment/Jet-Fuel-Energy-Prices-Dollars-perMillion-Btu-Beg/5w96-h3gp. Accessed 7 Dec 2014

299. Hamilton J D (2011) Historical oil shocks (No. w16790). National Bureau of Economic Research

300. Wright J C (2010) Oil: Demand, Supply and Trends in the United States. University of California Berkeley

301. Owen B (2008) Fuel Efficiency Development and Prediction Main Thematic Area: Climate Change. Omega, Manchester Metropolitan University

302. Bureau of Transportation Statistics. Table 4-21: Energy Intensity of Certificated Air Carriers, All Services (a).http://www.rita.dot. gov/bts/sites/rita.dot.gov.bts/files/publications/national_ transportation_statistics/html/table_04_21.html 